\title{
Macrofauna standing stock of the Dogger Bank. A comparison: III. 1950-54 versus 1985-87. A final summary
}

\author{
Ingrid Kröncke
}

\author{
Biologische Anstalt Helgoland; Notkestr. 31; D-W-2000 Hamburg 52, \\ Federal Republic of Germany \\ Present address: Forschungsinstitut Senckenberg, Schleusenstr. 39a, \\ $D-W$-2940 Wilhelmshaven, Federal Republic of Germany
}

\begin{abstract}
The macrofauna communities on the Dogger Bank in April/May 1985-87 were compared with those in April/May 1950-54 (Ursin, 1960). Unpublished data from Birkett on the central and western Dogger Bank from April/May 1952-54 were also used for the comparison. The changes in the communities from the fifties to the eighties were made clear by the increasing species numbers and in an increase or dominance of short-living opportunistic species. In contrast, a decrease in long-living bivalves was found. The total biomass in 1985-87 was 2.5 to 8 times higher than in 1950-54. Similarities between stations were below $20 \%$. Some hypotheses concerning natural and anthropogenic impacts are given to interpret the observed changes.
\end{abstract}

\section{INTRODUCTION}

Long-term changes in benthic communities have been documented for several coastal and nearshore European regions (cf. Pearson \& Barnett, 1987). For a long time, offshore regions in the North Sea, such as the Dogger Bank, were expected to be unaffected by anthropogenic environmental changes.

The Dogger Bank is a shallow water area in the southern central North Sea, $300 \mathrm{~km}$ long. 8000 years ago, the Bank was the southern border of the North Sea. The depths range between 18 and $40 \mathrm{~m}$.

The basis of this investigation was a comparison between recent data and data by Ursin (1960) on echinoderms, Kirkegaard (1969) on polychaetes, and Petersen (1977) on bivalves. Also unpublished data from Birkett (in Kröncke, 1991) for the western and central Dogger Bank from 1952-54 were used for comparison.

This work was part of the German interdisciplinary project "Biogeochemistry and the distribution of suspended matter in the North Sea and implications to Fisheries Biology" $(=\mathrm{TOSCH})$ investigating the situation in the southern North Sea with respect to the distribution of pollutants in water, sediment, invertebrate macrofauna and fish. Preliminary results have been published by Kröncke $(1988,1990)$. 


\section{MATERIAL AND METHODS}

\section{Area of investigation}

An example of Ursin's station nets (1960) in April/May 1950-54, the most complete one of 1952, is given in Figure 1a. Due to limitations in ship time in April/May 1985-87, only parts of the total Ursin station map were revisited (Fig. 1b; Table 1). Figure 2 and Table 2 show stations investigated by Birkett in April/May 1952-54.

Table 3 gives the sediment structure of the area under investigation in 1951-52 and 1985-87 as observed by sight, Figure 3 by grain size analysis of samples from July 1986 (Figge, pers. comm.). The depth of the area under investigation ranges from 30 to 35 meters.
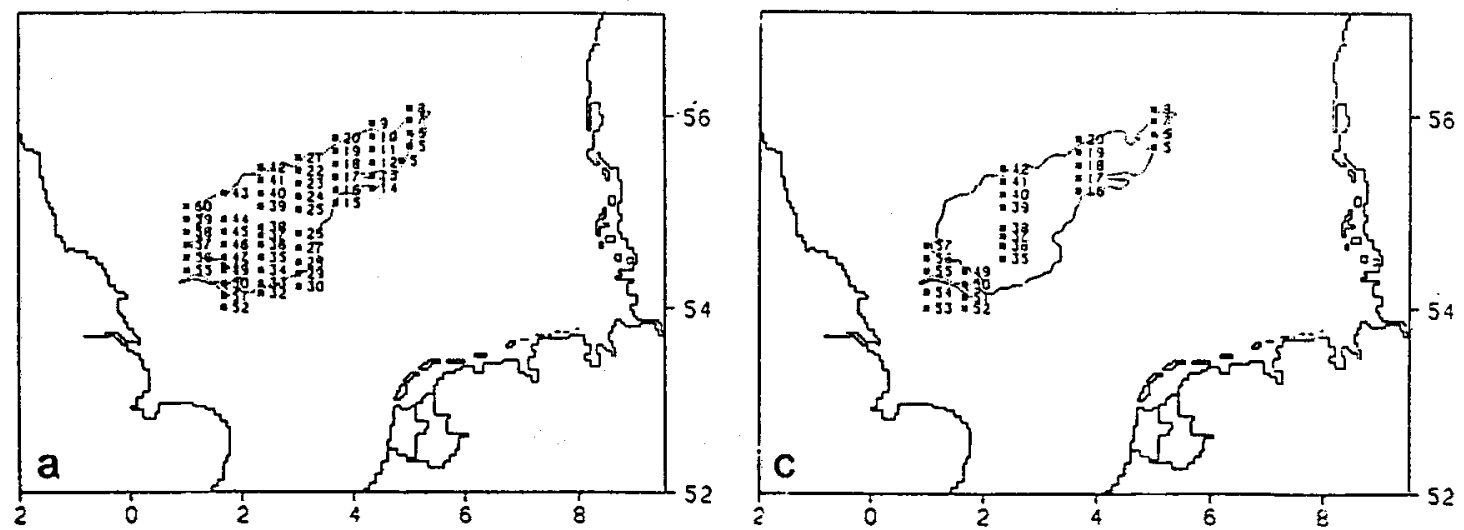

1952

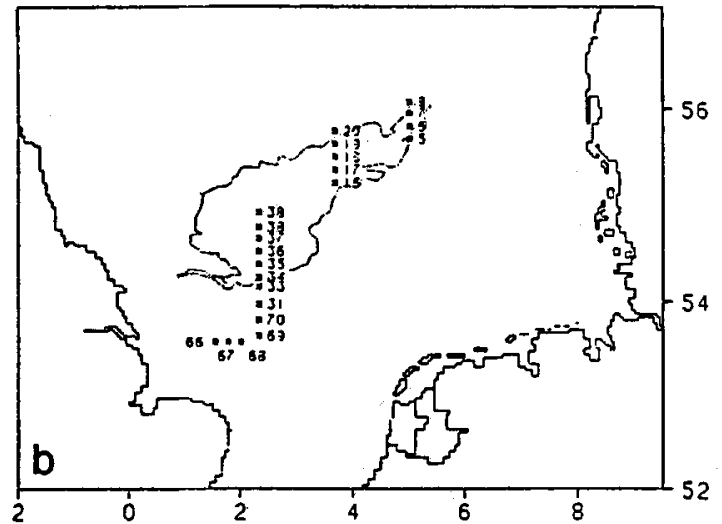

1986

1985

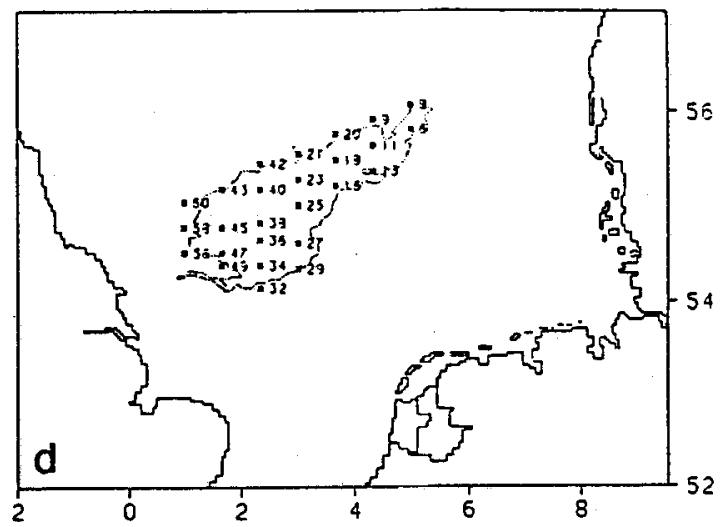

1987

Fig. 1. Station maps. a: Ursin's station map of April/May 1952, as exemplar of the years 1950 to 1954 ; b, c, d: station maps for April/May 1985 to 1987 

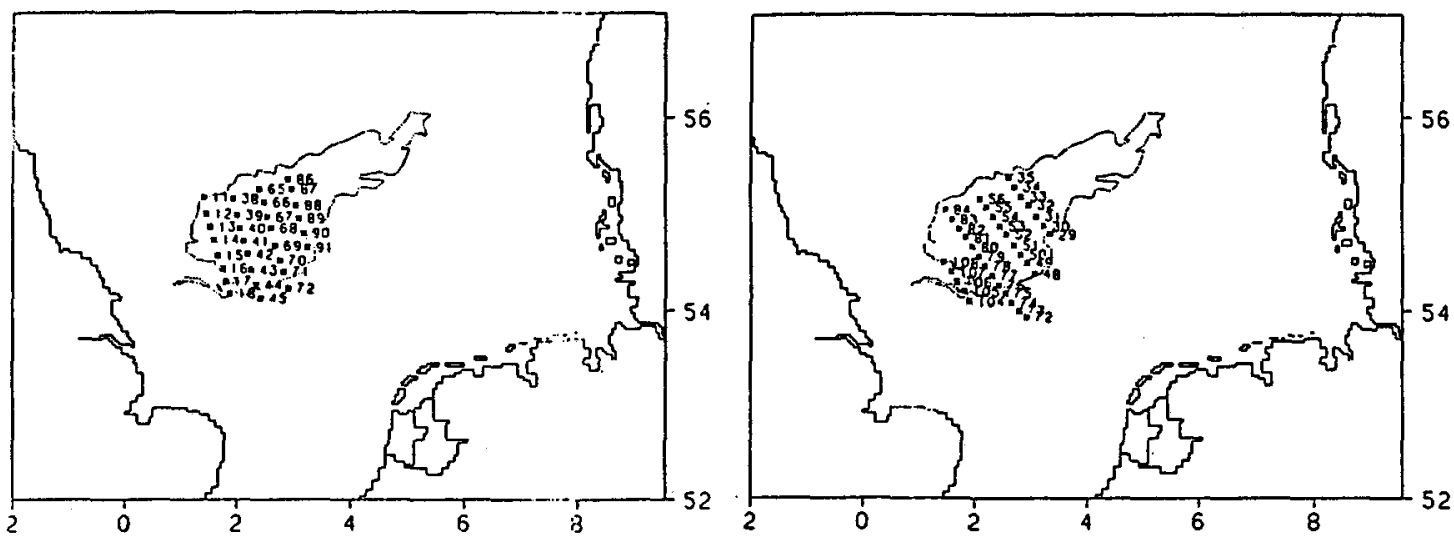

1952

1953

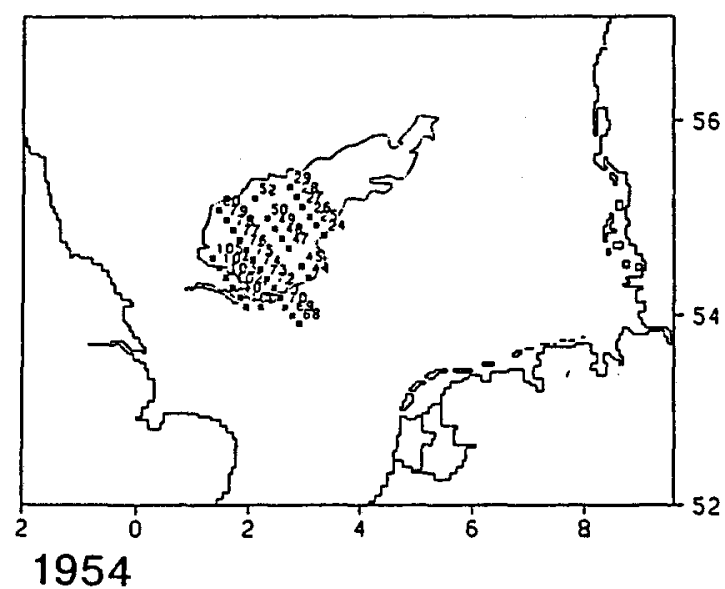

Fig. 2. Birkett's station maps for 1952 to 1954

\section{Sampling}

A $0.2 \mathrm{~m}^{2}$ Van Veen grab was used, similar to that described in Ursin (1960). Ursin's grab weighed $60 \mathrm{~kg}$ (Ursin, 1954), whereas the one used in 1985-87 had a weight of $150 \mathrm{~kg}$. A penetration of about $10 \mathrm{~cm}$ was achieved, which is a volume of about 10-12 $1 \mathrm{of}$ sediment. Ursin obtained about 8-10 1 in his grabs. Two grabs per station were taken. In contrast to Ursin, who sieved the samples through a mesh of $1.8 \mathrm{~mm}$, a sieve with a mesh size $1 \mathrm{~mm}$ was used during the recent investigations. All residue from the sieve was fixed in $4 \%$ formalin buffered with tetraborate. In the laboratory, the samples were stained with rose bengal to aid sorting. Birkett's $0.2 \mathrm{~m}^{2}$ Van-Veen grab weighed $116 \mathrm{~kg}$; the sieves he used had a mesh size of $1.5 \mathrm{~mm}$. 


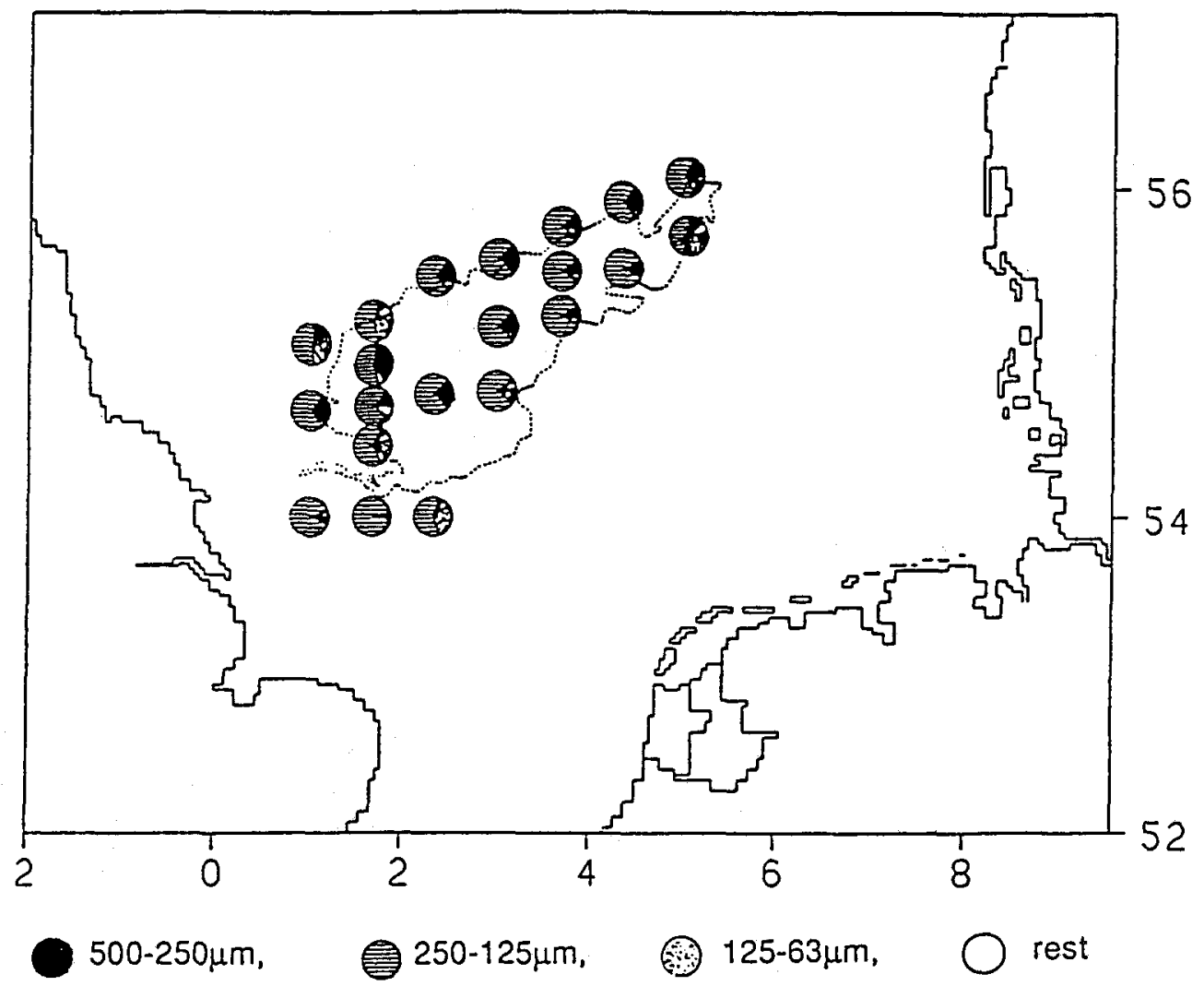

Fig. 3. Sediment classification according to grain size analysis (Figge, pers. comm.)

\section{Methodological comparison}

To assess the influence of the different grabs $(150 \mathrm{~kg}=\mathrm{G}-150 ; 90 \mathrm{~kg}=\mathrm{G}-90)$ and mesh sizes $(1.8 \mathrm{~mm}=\mathrm{M}-1.8 ; 1 \mathrm{~mm}=\mathrm{M}-1)$ on the comparability of the data, a methodological comparison was carried out in March 1988 at two stations on the Dogger Bank with different sediments: Station 6 with muddy fine sand and Station 18 showing fine sand with shells (Table 3). Five replicates per station were taken of each grab and mesh size. The fine material, washed through $1.8 \mathrm{~mm}$ mesh, was collected with the $1 \mathrm{~mm}$ mesh to assess the losses of individuals and species numbers using the $1.8 \mathrm{~mm}$ mesh.

\section{Biomass}

In the recent investigation, the biomass of the samples collected in April/May 1987 only was measured, because during that cruise the most complete station grid was investigated. In the former investigations, the biomass was determined per nautical square $(30 \times 60$ nautical miles) in the North Sea (Petersen, 1977). 
Table 1. Station list for April/May 1950-54 (Ursin) and 1985-87

\begin{tabular}{|c|c|c|c|c|c|c|c|c|c|c|c|}
\hline \multirow{2}{*}{$\begin{array}{l}\text { Stat. } \\
\text { Nr. }\end{array}$} & \multirow[t]{2}{*}{$\mathrm{N}$} & \multirow[t]{2}{*}{$\mathrm{E}$} & \multirow{2}{*}{$\begin{array}{l}\text { Depth } \\
\text { (m) }\end{array}$} & \multicolumn{8}{|c|}{ Sampling year } \\
\hline & & & & 1950 & 1951 & 1952 & 1953 & 1954 & 1985 & 1986 & 1987 \\
\hline 5 & $55^{\circ} 40^{\prime}$ & $05^{\circ} 00^{\prime}$ & 40 & $*$ & $*$ & $*$ & $*$ & $\because$ & $*$ & $*$ & \\
\hline 5.1 & $55^{\circ} 31^{\prime}$ & $04^{\circ} 51^{\prime}$ & 40 & & $*$ & $*$ & $*$ & & & & \\
\hline 6 & $55^{\circ} 48^{\prime}$ & $04^{\circ} 51^{\prime}$ & 34 & $*$ & $*$ & $*$ & $*$ & $*$ & $*$ & $*$ & $*$ \\
\hline 7 & $55^{\circ} 56^{\prime}$ & $04^{\circ} 51^{\prime}$ & 37 & $*$ & $*$ & $*$ & & $\approx$ & $*$ & $*$ & \\
\hline 8 & $56^{\circ} 04^{\prime}$ & $04^{\circ} 51^{\prime}$ & 43 & $*$ & $*$ & $*$ & $*$ & $*$ & $*$ & $*$ & $*$ \\
\hline 9 & $55^{\circ} 54^{\prime}$ & $04^{\circ} 20^{\prime}$ & 43 & $*$ & $*$ & $*$ & $*$ & $*$ & & & $*$ \\
\hline 10 & $55^{\circ} 46^{\prime}$ & $04^{\circ} 20^{\prime}$ & 40 & $*$ & $*$ & $*$ & $\approx$ & $*$ & & & \\
\hline 11 & $55^{\circ} 38^{\prime}$ & $04^{\circ} 20^{\prime}$ & 32 & $*$ & $*$ & $*$ & $*$ & $*$ & & & $*$ \\
\hline 12 & $55^{\circ} 30^{\prime}$ & $04^{\circ} 20^{\prime}$ & 34 & $\%$ & $\approx$ & $*$ & $*$ & $*$ & & & \\
\hline 13 & $55^{\circ} 22^{\prime}$ & $04^{\circ} 20^{\prime}$ & 42 & $*$ & $*$ & $*$ & $*$ & $*$ & & & $*$ \\
\hline 14 & $55^{\circ} 14^{\prime}$ & $04^{\circ} 20^{\prime}$ & 40 & & $*$ & $*$ & $*$ & $*$ & & & \\
\hline 15 & $55^{\circ} 05^{\prime}$ & $03^{\circ} 40^{\prime}$ & 40 & $*$ & $*$ & $*$ & $*$ & $*$ & $*$ & & \\
\hline 16 & $55^{\circ} 13^{\prime}$ & $03^{\circ} 40^{\prime}$ & 32 & $*$ & $\approx$ & $*$ & $*$ & & $*$ & $*$ & $*$ \\
\hline 17 & $55^{\circ} 21^{\prime}$ & $03^{\circ} 40^{\prime}$ & 26 & $*$ & $*$ & $*$ & $*$ & $*$ & $*$ & $*$ & \\
\hline 18 & $55^{\circ} 29^{\prime}$ & $03^{\circ} 40^{\prime}$ & 31 & $*$ & $\approx$ & $*$ & $*$ & $*$ & $*$ & $*$ & $*$ \\
\hline 19 & $55^{\circ} 37^{\prime}$ & $03^{\circ} 40^{\prime}$ & 36 & $*$ & $*$ & * & * & $\%$ & $*$ & $*$ & \\
\hline 20 & $55^{\circ} 45^{\prime}$ & $03^{\circ} 40^{\prime}$ & 47 & $*$ & $\%$ & $*$ & & & $*$ & $*$ & $*$ \\
\hline 21 & $55^{\circ} 33^{\prime}$ & $03^{\circ} 00^{\prime}$ & 40 & $*$ & $*$ & $\%$ & $*$ & $*$ & & & $*$ \\
\hline 22 & $55^{\circ} 25^{\prime}$ & $03^{\circ} 00^{\prime}$ & 32 & $*$ & $*$ & $*$ & $*$ & $*$ & & & \\
\hline 23 & $55^{\circ} 17^{\prime}$ & $03^{\circ} 00^{\prime}$ & 29 & $*$ & $*$ & $*$ & $*$ & $*$ & & & $*$ \\
\hline 24 & $55^{\circ} 09^{\prime}$ & $03^{\circ} 00^{\prime}$ & 25 & $*$ & $*$ & $*$ & $*$ & $*$ & & & \\
\hline 25 & $55^{\circ} 01^{\prime}$ & $03^{\circ} 00^{\prime}$ & 23 & & $*$ & $*$ & $*$ & $*$ & & & $*$ \\
\hline 27 & $54^{\circ} 37^{\prime}$ & $03^{\circ} 00^{\prime}$ & 33 & $*$ & $*$ & $*$ & $*$ & $*$ & & & $*$ \\
\hline 28 & $54^{\circ} 28^{\prime}$ & $03^{\circ} 00^{\prime}$ & 35 & & $*$ & & $*$ & $*$ & & & \\
\hline 29 & $54^{\circ} 21^{\prime}$ & $03^{\circ} 00^{\prime}$ & 39 & $*$ & & $*$ & $\approx$ & $*$ & & & $*$ \\
\hline 30 & $54^{\circ} 13^{\prime}$ & $03^{\circ} 00^{\prime}$ & 42 & & & $*$ & $*$ & & & & \\
\hline 31 & $54^{\circ} 00^{\prime}$ & $02^{\circ} 20^{\prime}$ & 50 & & & & & & & & $*$ \\
\hline 32 & $54^{\circ} 09^{\prime}$ & $02^{\circ} 20^{\prime}$ & 51 & & $*$ & * & & & & & $*$ \\
\hline 33 & $54^{\circ} 15^{\prime}$ & $02^{\circ} 20^{\prime}$ & 30 & & $\%$ & $*$ & & & $*$ & & \\
\hline 34 & $54^{\circ} 23^{\prime}$ & $02^{\circ} 20^{\prime}$ & 27 & & $*$ & $*$ & & & $\because$ & & \\
\hline 35 & $54^{\circ} 31^{\prime}$ & $02^{\circ} 20^{\prime}$ & 20 & & $*$ & $*$ & & & $*$ & $*$ & \\
\hline 36 & $54^{\circ} 39^{\prime}$ & $02^{\circ} 20^{\prime}$ & 18 & & $\approx$ & $*$ & & & $*$ & $*$ & $*$ \\
\hline 37 & $54^{\circ} 45^{\prime}$ & $02^{\circ} 20^{\prime}$ & 22 & & $\because$ & $*$ & & & $*$ & $*$ & \\
\hline 38 & $54^{\circ} 50^{\prime}$ & $02^{\circ} 20^{\prime}$ & 27 & & $*$ & $*$ & & & $*$ & $*$ & $*$ \\
\hline 39 & $55^{\circ} 03^{\prime}$ & $02^{\circ} 20^{\prime}$ & 35 & & $*$ & $*$ & & & & $*$ & \\
\hline 40 & $55^{\circ} 11^{\prime}$ & $02^{\circ} 20^{\prime}$ & 32 & & $\because$ & $*$ & & & & $*$ & $*$ \\
\hline 41 & $55^{\circ} 19^{\prime}$ & $02^{\circ} 20^{\prime}$ & 37 & & $\approx$ & $*$ & & & & $*$ & \\
\hline 42 & $55^{\circ} 27^{\prime}$ & $02^{\circ} 20^{\prime}$ & 44 & & $*$ & $*$ & & & & $\%$ & $*$ \\
\hline 43 & $55^{\circ} 11^{\prime}$ & $01^{\circ} 40^{\prime}$ & 36 & & $*$ & $*$ & & & & & $*$ \\
\hline 45 & $54^{\circ} 47^{\prime}$ & $01^{\circ} 40^{\prime}$ & 23 & & $*$ & $*$ & & & & & $*$ \\
\hline 46 & $54^{\circ} 39^{\prime}$ & $01^{\circ} 40^{\prime}$ & 20 & $\approx$ & $*$ & $*$ & $*$ & $*$ & & & \\
\hline 47 & $54^{\circ} 31^{\prime}$ & $01^{\circ} 40^{\prime}$ & 18 & & $*$ & $*$ & & & & & $*$ \\
\hline 49 & $54^{\circ} 23^{\prime}$ & $01^{\circ} 40^{\prime}$ & 48 & & $*$ & $*$ & & & & $*$ & $*$ \\
\hline 50 & $54^{\circ} 15^{\prime}$ & $01^{\circ} 40^{\prime}$ & 48 & & $*$ & $*$ & & & & $*$ & \\
\hline 51 & $54^{\circ} 07^{\prime}$ & $01^{\circ} 40^{\prime}$ & 68 & & $*$ & $*$ & & & & $*$ & \\
\hline 52 & $54^{\circ} 00^{\prime}$ & $01^{\circ} 40^{\prime}$ & 37 & & & $*$ & & & & $*$ & \\
\hline 53 & $54^{\circ} 00^{\prime}$ & $01^{\circ} 00^{\prime}$ & 46 & & & & & & & $*$ & \\
\hline 54 & $54^{\circ} 10^{\prime}$ & $01^{\circ} 00^{\prime}$ & 45 & & & & & & & $\because$ & \\
\hline 55 & $54^{\circ} 23^{\prime}$ & $01^{\circ} 00^{\prime}$ & 46 & & $\because$ & $*$ & & & & $*$ & \\
\hline 56 & $54^{\circ} 31^{\prime}$ & $01^{\circ} 00^{\prime}$ & 55 & & $*$ & $\because$ & & & & $*$ & $\approx$ \\
\hline 57 & $54^{\circ} 39^{\prime}$ & $01^{\circ} 00^{\prime}$ & 60 & & $*$ & $*$ & & & & $*$ & \\
\hline 58 & $54^{\circ} 47^{\prime}$ & $01^{\circ} 00^{\prime}$ & 50 & & $*$ & $*$ & & & & & $*$ \\
\hline 60 & $55^{\circ} 03^{\prime}$ & $01^{\circ} 00^{\prime}$ & 61 & & $*$ & $*$ & & & & & $*$ \\
\hline
\end{tabular}


Table 2. Birkett's station list for 1952-1954

\begin{tabular}{|c|c|c|c|c|c|}
\hline $\begin{array}{c}1952 \\
\text { Stat. Nr. }\end{array}$ & $\mathrm{N}$ & $E$ & $\begin{array}{c}1954 \\
\text { Stat. Nr. }\end{array}$ & $\mathrm{N}$ & $\mathrm{E}$ \\
\hline 11 & $55^{\circ} 09^{\prime}$ & $01^{\circ} 25^{\prime}$ & 26 & $55^{\circ} 00^{\prime}$ & $03^{\circ} 06^{\prime}$ \\
\hline 12 & $54^{\circ} 59^{\prime}$ & $01^{\circ} 27^{\prime}$ & 27 & $55^{\circ} 06^{\prime}$ & $02^{\circ} 58^{\prime}$ \\
\hline 13 & $54^{\circ} 51^{\prime}$ & $01^{\circ} 31^{\prime}$ & 28 & $55^{\circ} 12^{\prime}$ & $02^{\circ} 52^{\prime}$ \\
\hline 14 & $54^{\circ} 43^{\prime}$ & $01^{\circ} 35^{\prime}$ & 29 & $55^{\circ} 18^{\prime}$ & $02^{\circ} 44^{\prime}$ \\
\hline 15 & $54^{\circ} 33^{\prime}$ & $01^{\circ} 39^{\prime}$ & 44 & $54^{\circ} 23^{\prime}$ & $03^{\circ} 04^{\prime}$ \\
\hline 16 & $54^{\circ} 25^{\prime}$ & $01^{\circ} 44^{\prime}$ & 45 & $54^{\circ} 30^{\prime}$ & $02^{\circ} 57^{\prime}$ \\
\hline 17 & $54^{\circ} 17^{\prime}$ & $01^{\circ} 48^{\prime}$ & 47 & $54^{\circ} 41^{\prime}$ & $02^{\circ} 43^{\prime}$ \\
\hline 18 & $54^{\circ} 10^{\prime}$ & $01^{\circ} 52^{\prime}$ & 48 & $54^{\circ} 47^{\prime}$ & $02^{\circ} 36^{\prime}$ \\
\hline 38 & $55^{\circ} 08^{\prime}$ & $01^{\circ} 56^{\prime}$ & 49 & $54^{\circ} 53^{\prime}$ & $02^{\circ} 28^{\prime}$ \\
\hline 39 & $54^{\circ} 58^{\prime}$ & $02^{\circ} 00^{\prime}$ & 50 & $54^{\circ} 59^{\prime}$ & $02^{\circ} 20^{\prime}$ \\
\hline 40 & $54^{\circ} 50^{\prime}$ & $02^{\circ} 03^{\prime}$ & 51 & $54^{\circ} 05^{\prime}$ & $02^{\circ} 13^{\prime}$ \\
\hline 41 & $54^{\circ} 42^{\prime}$ & $02^{\circ} 07^{\prime}$ & 52 & $55^{\circ} 11^{\prime}$ & $02^{\circ} 06^{\prime}$ \\
\hline 42 & $54^{\circ} 34^{\prime}$ & $02^{\circ} 11^{\prime}$ & 68 & $53^{\circ} 56^{\prime}$ & $02^{\circ} 55^{\prime}$ \\
\hline 43 & $54^{\circ} 24^{\prime}$ & $02^{\circ} 15^{\prime}$ & 69 & $54^{\circ} 00^{\prime}$ & $02^{\circ} 48^{\prime}$ \\
\hline 44 & $54^{\circ} 15^{\prime}$ & $02^{\circ} 20^{\prime}$ & 70 & $54^{\circ} 05^{\prime}$ & $02^{\circ} 40^{\prime}$ \\
\hline 45 & $54^{\circ} 07^{\prime}$ & $02^{\circ} 25^{\prime}$ & 71 & $54^{\circ} 11^{\prime}$ & $02^{\circ} 34^{\prime}$ \\
\hline 65 & $55^{\circ} 14^{\prime}$ & $02^{\circ} 24^{\prime}$ & 72 & $54^{\circ} 17^{\prime}$ & $02^{\circ} 27^{\prime}$ \\
\hline 66 & $55^{\circ} 06^{\prime}$ & $02^{\circ} 29^{\prime}$ & 73 & $54^{\circ} 22^{\prime}$ & $02^{\circ} 19^{\prime}$ \\
\hline 67 & $54^{\circ} 57^{\prime}$ & $02^{\circ} 32^{\prime}$ & 74 & $54^{\circ} 28^{\prime}$ & $02^{\circ} 12^{\prime}$ \\
\hline 68 & $54^{\circ} 50^{\prime}$ & $02^{\circ} 36^{\prime}$ & 75 & $54^{\circ} 34^{\prime}$ & $02^{\circ} 04^{\prime}$ \\
\hline 69 & $54^{\circ} 39^{\prime}$ & $02^{\circ} 40^{\prime}$ & 76 & $54^{\circ} 40^{\prime}$ & $01^{\circ} 57^{\prime}$ \\
\hline 70 & $54^{\circ} 30^{\prime}$ & $02^{\circ} 45^{\prime}$ & 77 & $54^{\circ} 46^{\prime}$ & $01^{\circ} 50^{\prime}$ \\
\hline 71 & $54^{\circ} 23^{\prime}$ & $02^{\circ} 49^{\prime}$ & 78 & $54^{\circ} 52^{\prime}$ & $01^{\circ} 43^{\prime}$ \\
\hline 72 & $54^{\circ} 13^{\prime}$ & $02^{\circ} 54^{\prime}$ & 79 & $54^{\circ} 58^{\prime}$ & $01^{\circ} 36^{\prime}$ \\
\hline 86 & $55^{\circ} 20^{\prime}$ & $02^{\circ} 53^{\prime}$ & 80 & $55^{\circ} 04^{\prime}$ & $01^{\circ} 28^{\prime}$ \\
\hline 87 & $55^{\circ} 14^{\prime}$ & $02^{\circ} 58^{\prime}$ & 100 & $54^{\circ} 05^{\prime}$ & $01^{\circ} 57^{\prime}$ \\
\hline 88 & $55^{\circ} 04^{\prime}$ & $03^{\circ} 02^{\prime}$ & 101 & $54^{\circ} 11^{\prime}$ & $01^{\circ} 50^{\prime}$ \\
\hline 89 & $54^{\circ} 56^{\prime}$ & $03^{\circ} 05^{\prime}$ & 102 & $54^{\circ} 17^{\prime}$ & $01^{\circ} 42^{\prime}$ \\
\hline 90 & $54^{\circ} 47^{\prime}$ & $03^{\circ} 10^{\prime}$ & 103 & $54^{\circ} 23^{\prime}$ & $01^{\circ} 35^{\prime}$ \\
\hline \multirow[t]{2}{*}{91} & $54^{\circ} 38^{\prime}$ & $03^{\circ} 14^{\prime}$ & 104 & $54^{\circ} 29^{\prime}$ & $01^{\circ} 28^{\prime}$ \\
\hline & & & 105 & $54^{\circ} 35^{\prime}$ & $01^{\circ} 21^{\prime}$ \\
\hline \multicolumn{6}{|l|}{ Stat. Nr. } \\
\hline 29 & $54^{\circ} 48^{\prime}$ & $03^{\circ} 21^{\prime}$ & 74 & $54^{\circ} 05^{\prime}$ & $02^{\circ} 40^{\prime}$ \\
\hline 30 & $54^{\circ} 53^{\prime}$ & $03^{\circ} 14^{\prime}$ & 75 & $54^{\circ} 11^{\prime}$ & $02^{\circ} 33^{\prime}$ \\
\hline 31 & $54^{\circ} 59^{\prime}$ & $03^{\circ} 06^{\prime}$ & 76 & $54^{\circ} 16^{\prime}$ & $02^{\circ} 26^{\prime}$ \\
\hline 32 & $55^{\circ} 06^{\prime}$ & $02^{\circ} 58^{\prime}$ & 77 & $54^{\circ} 22^{\prime}$ & $02^{\circ} 19^{\prime}$ \\
\hline 33 & $55^{\circ} 11^{\prime}$ & $02^{\circ} 50^{\prime}$ & 78 & $54^{\circ} 28^{\prime}$ & $02^{\circ} 11^{\prime}$ \\
\hline 34 & $55^{\circ} 17^{\prime}$ & $02^{\circ} 43^{\prime}$ & 79 & $54^{\circ} 34^{\prime}$ & $02^{\circ} 05^{\prime}$ \\
\hline 35 & $55^{\circ} 23^{\prime}$ & $02^{\circ} 36^{\prime}$ & 80 & $54^{\circ} 50^{\prime}$ & $01^{\circ} 58^{\prime}$ \\
\hline 48 & $54^{\circ} 23^{\prime}$ & $03^{\circ} 04^{\prime}$ & 81 & $54^{\circ} 46^{\prime}$ & $01^{\circ} 51^{\prime}$ \\
\hline 49 & $54^{\circ} 30^{\prime}$ & $02^{\circ} 56^{\prime}$ & 82 & $54^{\circ} 51^{\prime}$ & $01^{\circ} 44^{\prime}$ \\
\hline 50 & $54^{\circ} 35^{\prime}$ & $02^{\circ} 49^{\prime}$ & 83 & $54^{\circ} 57^{\prime}$ & $01^{\circ} 36^{\prime}$ \\
\hline 51 & $54^{\circ} 51^{\prime}$ & $02^{\circ} 42^{\prime}$ & 84 & $55^{\circ} 03^{\prime}$ & $01^{\circ} 29^{\prime}$ \\
\hline 52 & $54^{\circ} 48^{\prime}$ & $02^{\circ} 34^{\prime}$ & 104 & $54^{\circ} 06^{\prime}$ & $01^{\circ} 55^{\prime}$ \\
\hline 53 & $54^{\circ} 53^{\prime}$ & $02^{\circ} 27^{\prime}$ & 105 & $54^{\circ} 12^{\prime}$ & $01^{\circ} 49^{\prime}$ \\
\hline 54 & $54^{\circ} 59^{\prime}$ & $02^{\circ} 20^{\prime}$ & 106 & $54^{\circ} 18^{\prime}$ & $01^{\circ} 41^{\prime}$ \\
\hline 55 & $55^{\circ} 05^{\prime}$ & $02^{\circ} 13^{\prime}$ & 107 & $54^{\circ} 24^{\prime}$ & $01^{\circ} 35^{\prime}$ \\
\hline 56 & $55^{\circ} 10^{\prime}$ & $02^{\circ} 06^{\prime}$ & 108 & $54^{\circ} 30^{\prime}$ & $01^{\circ} 27^{\prime}$ \\
\hline 72 & $53^{\circ} 57^{\prime}$ & $02^{\circ} 56^{\prime}$ & & & \\
\hline 73 & $54^{\circ} 00^{\prime}$ & $02^{\circ} 48^{\prime}$ & & & \\
\hline
\end{tabular}


Table 3. Sediment types for 1950-1954 (Ursin) and 1985-1987

\begin{tabular}{|c|c|c|c|}
\hline Stat. Nr. & $(\mathrm{m})$ & $1950-1954$ & 1985-1987 \\
\hline 5 & 40 & Fine sand & Fine sand \\
\hline 6 & 34 & Fine sand & Fine sand \\
\hline 7 & 37 & Fine sand & Fine sand \\
\hline 8 & 43 & Coarse sand, stones & Fine sand \\
\hline 9 & 4 & Fine sand, dead shells & Fine sand, dead shells \\
\hline 11 & 32 & Fine sand, dead shells & Fine sand, dead shells \\
\hline 13 & 42 & Muddy fine sand & Fine sand, dead shells \\
\hline 15 & 40 & Muddy fine sand & Fine sand, dead shells \\
\hline 16 & 32 & Fine sand & Fine sand, dead shells \\
\hline 17 & 26 & Fine sand, dead shells & Fine sand, dead shells \\
\hline 18 & 31 & Fine sand, dead shells & Fine sand, dead shells \\
\hline 19 & 36 & Fine sand, dead shells & Fine sand, dead shells \\
\hline 20 & 47 & Fine sand, dead shells & Fine sand \\
\hline 21 & 40 & Fine sand, dead shells & Fine sand, dead shells \\
\hline 23 & 29 & Fine sand, dead shells & Fine sand, dead shells \\
\hline 25 & 23 & Fine sand, dead shells & Fine sand, dead shells \\
\hline 27 & 33 & Muddy fine sand & Fine sand, dead shells \\
\hline 29 & 39 & Muddy fine sand & Fine sand, dead shells \\
\hline 31 & 50 & Muddy fine sand & Muddy fine sand \\
\hline 32 & 51 & Mud. f. s., dead shells, stones & Fine sand \\
\hline 33 & 30 & Coarse sand & Fine sand \\
\hline 34 & 27 & Coarse sand & Fine sand, dead shells \\
\hline 35 & 20 & Fine sand, dead shells & Fine sand, dead shells \\
\hline 36 & 18 & Fine sand, dead shells & Fine sand, dead shells \\
\hline 37 & 22 & Fine sand, dead shells & Fine sand, dead shells \\
\hline 38 & 27 & Fine sand, dead shells & Fine sand, dead shells \\
\hline 39 & 35 & Fine sand, dead shells & Fine sand, dead shells \\
\hline 40 & 32 & Fine sand, dead shells & Fine sand, dead shells \\
\hline 41 & 37 & Fine sand, dead shells & Fine sand, dead shells \\
\hline 42 & 44 & Fine sand & Fine sand, dead shells \\
\hline 43 & 36 & Fine sand & Fine sand, dead shells \\
\hline 45 & 23 & Coarse sand, stones & Fine sand \\
\hline 47 & 18 & Fine sand & Fine sand \\
\hline 49 & 48 & Muddy fine sand & Fine sand \\
\hline 50 & 48 & Muddy fine sand & Fine sand \\
\hline 51 & 68 & Muddy fine sand & Fine sand \\
\hline 52 & 37 & Muddy fine sand & Muddy fine sand \\
\hline 53 & 46 & Muddy fine sand & Muddy fine sand \\
\hline 54 & 45 & Muddy fine sand & Muddy fine sand \\
\hline 55 & 46 & Fine sand & Muddy fine sand \\
\hline 56 & 55 & Muddy fine sand & Muddy fine sand \\
\hline 57 & 60 & Muddy fine sand & Muddy fine sand \\
\hline 58 & 50 & Muddy fine sand & Muddy fine sand \\
\hline 60 & 61 & Muddy fine sand & Muddy fine sand \\
\hline
\end{tabular}

To determine the total biomass, the ash-free dry weight $\left(24 \mathrm{~h}\right.$ at $80^{\circ} \mathrm{C}$ and $6 \mathrm{~h}$ at $480^{\circ} \mathrm{C}$, respectively) of organisms was determined. Using the conversion rates for wet weight and ash-free dry weight given by Salzwedel et al. (1985), the total wet weight per nautical square was determined. 


\section{Cluster analyses}

The cluster analyses were performed with the "percentage similarity" coefficient after Whittaker \& Fairbanks (1958), where $\dot{s}=\Sigma \min \mathrm{p}_{\mathrm{i}}\left(\mathrm{xlog}_{2}\right), \mathrm{p}_{\mathrm{i}}=$ percentage species abundance.

\section{Similarities between stations}

The percentage species similarity defined as $(c \times 100) /(a+b-c)$ (Greig-Smith, 1964), where $a=$ the number of species present in the first sample, $b=$ the number of species present in the second sample, and $c=$ the number of common species present in both samples, deals with the absence and presence of species per station. Concerning the different species abundances per station, the similarity coefficient of Whittaker \& Fairbanks (1958) was also used.

\section{Abundance-Biomass-Comparison curves}

For this method, introduced by Warwick (1986), the species are ranked in order of importance on the $\mathrm{x}$-axis (logarithmic scale) with percentage dominance on the $y$-axis (cumulative scale).

Under stable undisturbed conditions, the biomass is dominated by a few large species, each represented by few individuals. In this case, the biomass curve is above the abundance curve. Under moderate disturbances, the large dominants are eliminated from the community, and the inequality in size between the numerical and biomass dominants is reduced. The $A B C$ curves are close together. As disturbance becomes more severe, benthic communities become dominated numerically by small species. Then the abundance curve moves above the biomass curve.

\section{RESULTS}

\section{Sediment comparison}

Table 3 shows the sediment characterization, judged by sight, during the periods 1950-54 (only Ursin) and 1985-87. During both investigations, the sediments of the Dogger Bank proper were characterized as fine sands with a varying amount of dead shells, whereas the sediments of the deeper parts were said to be muddy fine sands. Discrepancies are limited to stations $8,33,34$ and 45 , with Ursin finding coarse sands and myself finding fine sands. Figure 3 confirms that sediments of the Dogger Bank proper were mainly fine sands, whereas at greater depths muddy sands were found.

\section{Methodological comparison \\ Different grab weights}

In comparing the different grab weights (G-90 and G-150), no differences regarding the percentage of individuals per species (Fig. 4), presence/absence of species (Table 4), species numbers (Table 5) and diversities and evenness (Table 6), could be discerned between station 6 with muddy fine sands and station 18 with fine sands, using several 

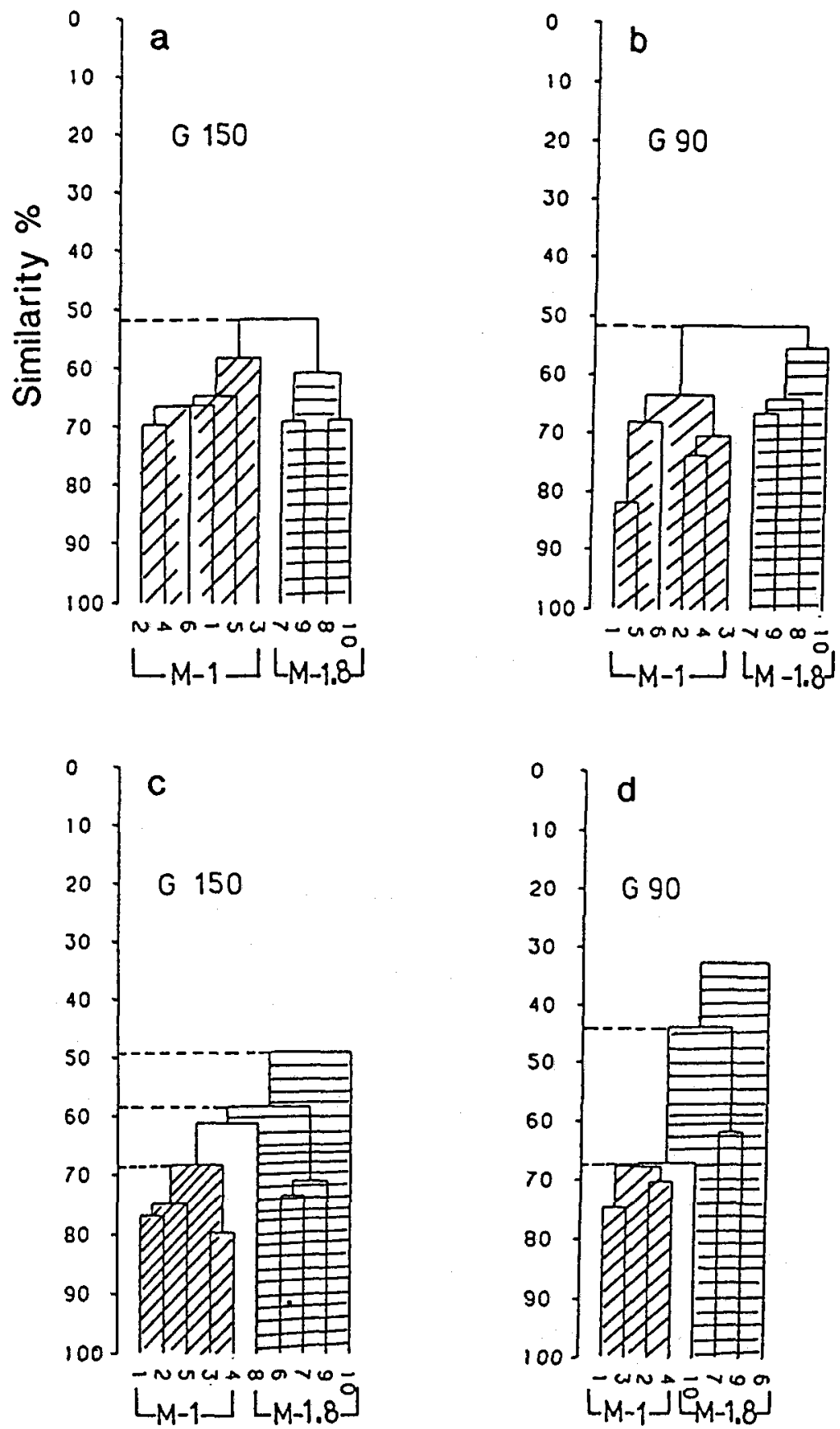

Fig. 4. Similarities between samples sieved over the mesh sizes $1 \mathrm{~mm}(\mathrm{M}-1)$ and $1.8 \mathrm{~mm}(\mathrm{M}-1.8)$ and between samples taken with grab weights of $150 \mathrm{~kg}(\mathrm{G}-150)$ and of $90 \mathrm{~kg}(\mathrm{G}-90)$ at station $6(\mathrm{a}, \mathrm{b})$ and $18(\mathrm{c}, \mathrm{d})$ 
Table 4. Similarities (\%, Greig-Smith coefficient) between samples taken with grabs of different weights $(150 \mathrm{~kg}=\mathrm{G}-150$ and $90 \mathrm{~kg}=\mathrm{G}-90)$ and sieved over different mesh sizes (1 $\mathrm{mm}=\mathrm{M}-1$ and $1.8 \mathrm{~mm}=\mathrm{M}-1.8$ )

\begin{tabular}{|lcccc|}
\hline Station 6 & G-150/M-1 & G-150/M-1.8 & G-90/M-1 & G-90/M-1.8 \\
\hline G-150/M-1 & 37.5 & 40.3 & 38.0 & 35.3 \\
G-150/M-1.8 & & 38.7 & 36.5 & 34.7 \\
G-90/M-1 & & & 40.5 & 37.9 \\
G-90/M-1.8 & & & & 34.4 \\
\hline Station 18 & G-150/M-1 & G-150/M-1.8 & G-90/M-1 & G-90/M-1.8 \\
\hline G-150/M-1 & 53.3 & 51.7 & 42.3 & 44.8 \\
G-150/M-1.8 & & 55.4 & 45.8 & 44.6 \\
G-90/M-1 & & & 46.3 & 45.1 \\
G-90/M-1.8 & & & & 46.2 \\
\hline
\end{tabular}

Table 5. Significance of difference in species numbers due to different grab weights (G-150 and G-90) and mesh sizes $1 \mathrm{~mm}$ and $1.8 \mathrm{~mm}$ (M-1 and M-1.8). ns = not significant

\begin{tabular}{|c|c|c|c|c|c|}
\hline & G-150/M-1 & G-150/M-1.8 & G-90/M-1 & G-90/M-1.8 & a \\
\hline \multirow[t]{4}{*}{ Stat. 6} & $*$ & $*$ & & & ns \\
\hline & & $x^{*}$ & & $\because$ & ns \\
\hline & & & $*$ & $\div$ & ns \\
\hline & $*$ & & $*$ & & ns \\
\hline \multirow[t]{4}{*}{ Stat. 18} & $*$ & $*$ & & & $<0.01$ \\
\hline & & $*$ & & $*$ & ns \\
\hline & & & $*$ & $*$ & $<0.01$ \\
\hline & $\because$ & & $*$ & & ns \\
\hline
\end{tabular}

methods. All calculations showed that the natural variation within the 5 replicates taken per grab was similar to the variation which occurred when different grab weights were used.

\section{Different mesh sizes}

The community structure was not affected by using different mesh sizes (Fig. 5; Table 4), nor did species numbers (Table 5), diversities and evenness (Table 6) show any significant differences. Again, the natural variation within the 5 replicates sieved per mesh size was similar to that using different mesh sizes. One significant difference using the two mesh sizes was the loss of small individuals through the bigger mesh size M-1.8 during 1950-54. It appeared that almost all of the amphipods were lost through the $M$ 1.8. Therefore, this order was disregarded in the long-term comparison. For other ecologically important species or for species which had been found to increase in occurrence during the eighties, the individual numbers in 1985-87 were corrected by the loss through mesh size $1.8 \mathrm{~mm}(\mathrm{M}-1.8)$ (Table 7 ). Only corrected data were used for the long-term comparison. 

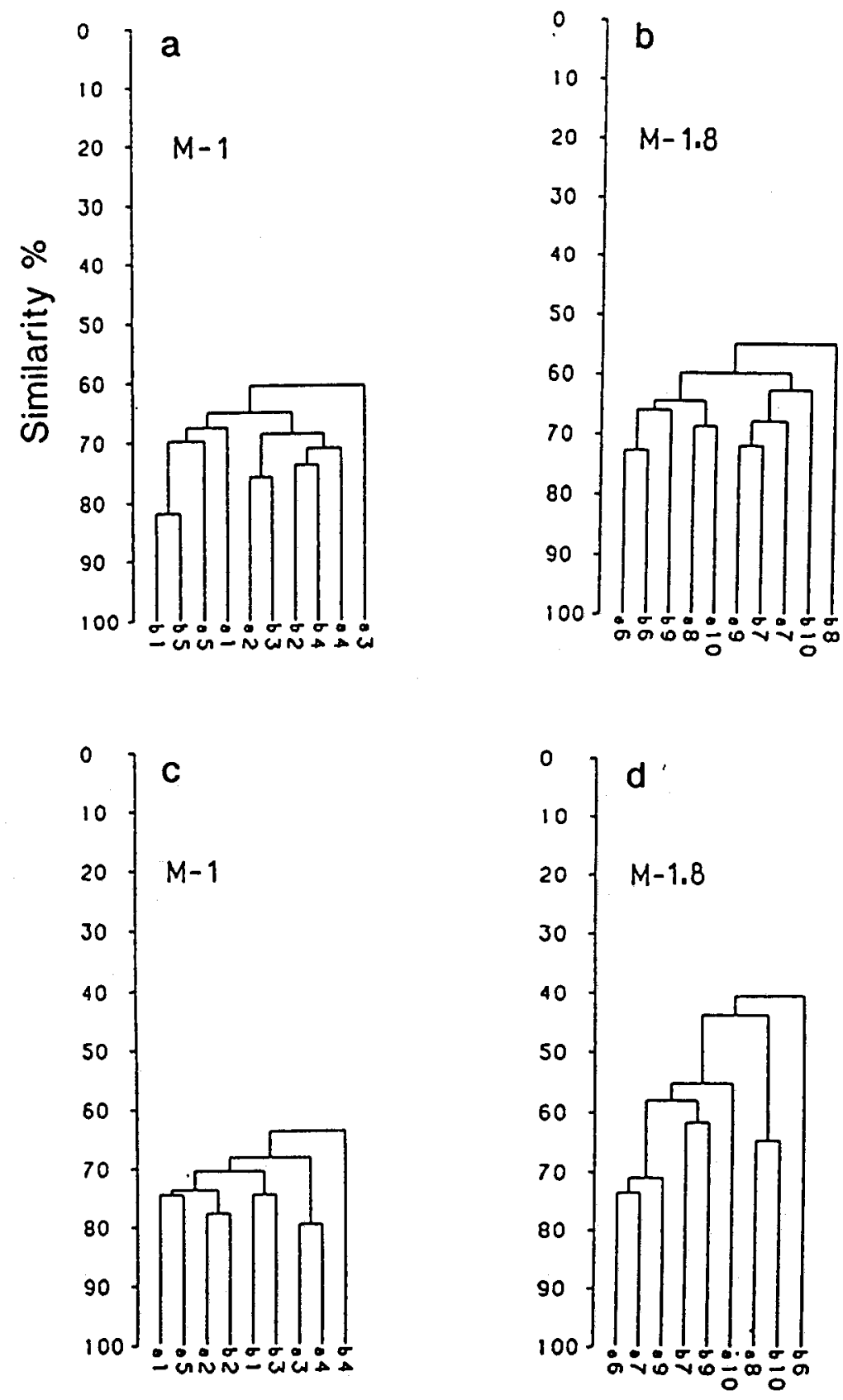

Fig. 5. Similarities between samples (a taken with G-150, b with G-90) sieved over mesh size $1 \mathrm{~mm}$ $(\mathrm{M}-1)$ and $1.8 \mathrm{~mm}(\mathrm{M}-1.8)$ at station $6(\mathrm{a}, \mathrm{b})$ and $18(\mathrm{c}, \mathrm{d})$ 
Table 6. Mean diversities $(\mathrm{H})$ and evenness $(\mathrm{J})$ for M-1, M-1.8, G-150 und G-90 of samples from stations 6 and 18

\begin{tabular}{|llllll|}
\hline Station & & 6 & & & 18 \\
& $\mathrm{H}$ & & $\mathrm{J}$ & $\mathrm{H}$ & $\mathrm{J}$ \\
\hline G-150/M-1 & 3.4 & 0.7 & 4.0 & 0.8 \\
G-150/M-1.8 & 3.6 & 0.9 & 4.2 & 0.9 \\
G-90/M-1 & 3.5 & 0.8 & 4.0 & 0.8 \\
G-90/M-1.8 & 3.6 & 0.8 & 3.7 & 0.8 \\
\hline
\end{tabular}

The methodological comparison had been completed before the unpublished data of Birkett became available. Since Birkett employed intermediate grab weight $(116 \mathrm{~kg})$ and mesh size $(1.5 \mathrm{~mm})$, his results fall into the same range of similarities observed when using the sampling techniques of Ursin and myself.

\section{Faunistic comparison}

The following results refer only to polychaetes, echinoderms and bivalves.

\section{Species numbers, diversities and evenness}

During the fifties, the mean species numbers were 12 to 14 per $0.2 \mathrm{~m}^{2}$ (Tables 8,9 ). In 1985-87, I found 23 to 29 per $0.2 \mathrm{~m}^{2}$. The mean diversities calculated from Ursin's data range between 2.5 and 2.7 (Table 10); those calculated from Birkett's data amount to 2.9 (Table 9). During the eighties the mean diversities ranged between 3.2 and 3.4 (Table 10).

During 1950-54 the mean evenness was 0.8 (Tables 9, 11), whereas during 1985-87 an evenness of 0.7 was calculated (Table 11 ).

\section{Species abundance}

Comparison of the abundance data between the fifties and the eighties (Table 12) revealed a considerable increase in numbers of the opportunistic short-living, depositfeeding polychaetes such as Nephtys cirrosa, Spiophanes bombyx and Scoloplos armiger, the ophiurid Amphiura filiformis and the bivalve Montacuta bidentata. Similarly, the individual numbers of the carnivorous polychaetes, e.g. the genus Nephtys and Goniada maculata, increased. Other short-living, deposit-feeding species such as the bivalves Abra prismatica and Tellina fabula, and the polychaetes Chaetozone setosa and Magelona spp. showed similar abundances. In contrast, the individual numbers of longliving bivalves such as Ensis ensis, Mactra c. cinerea and Spisula subtruncata decreased. During the eighties, the sea-urchin Echinocardium cordatum occurred in the same numbers as during the fifties.

\section{Cluster analyses}

The cluster analyses derived from Ursin's (1951/52), Birkett's (1953/54) and my data (1985-87) resulted in two main communities: one on the Dogger Bank proper and another one at its south-western boundary (Fig. 6). 


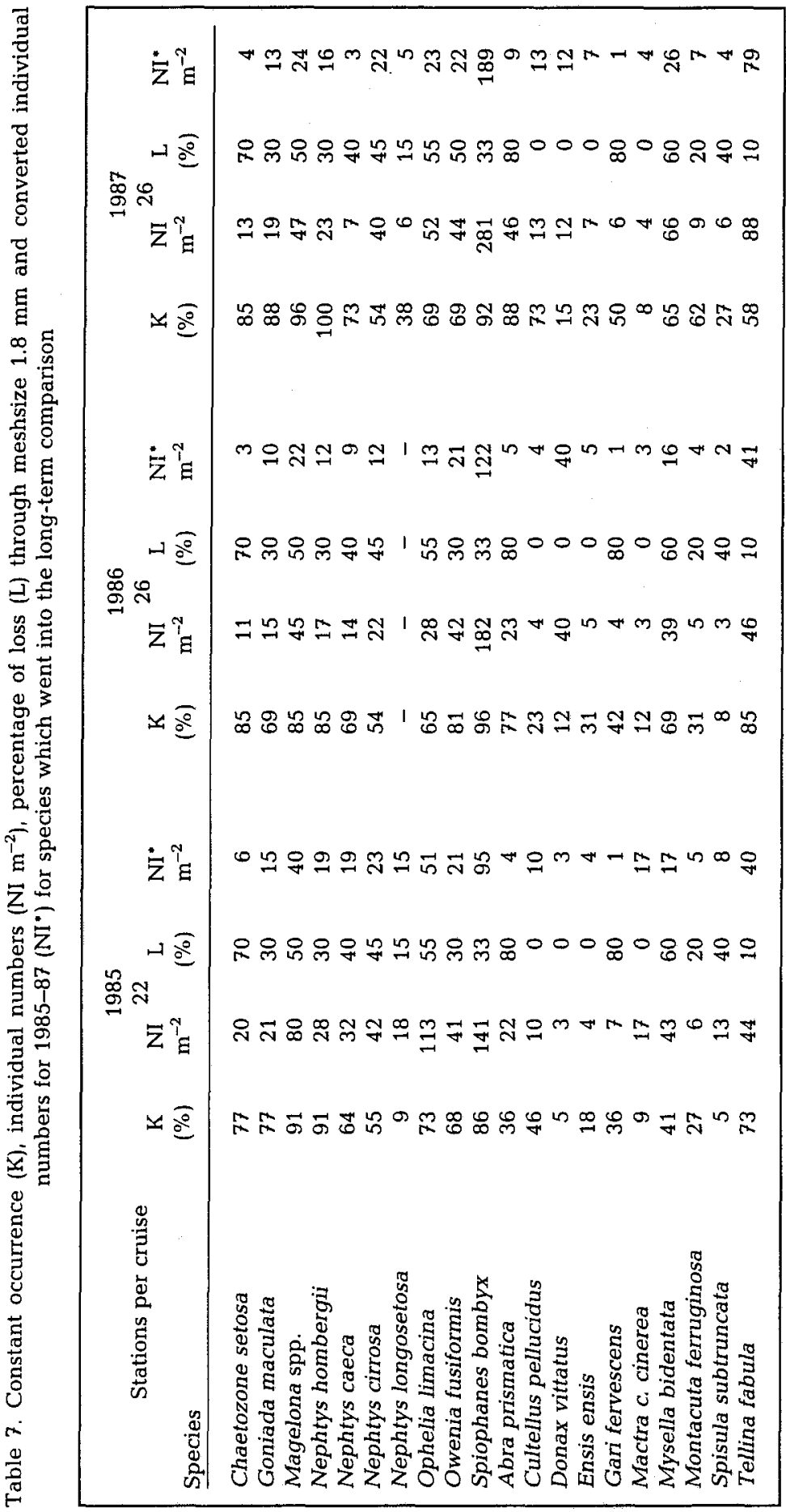


Table 8. Mean species number for 1985-1987 and 1950-1954 (Ursin)

\begin{tabular}{|c|c|c|c|c|c|c|c|c|}
\hline \multirow[t]{2}{*}{ Stat. } & \multicolumn{3}{|c|}{ Species number $/ 0.2 \mathrm{~m}^{2}$} & \multicolumn{5}{|c|}{ Species number $/ 0.2 \mathrm{~m}^{2}$} \\
\hline & 1985 & 1986 & 1987 & 1950 & 1951 & 1952 & 1953 & 1954 \\
\hline 5 & 28 & 30 & & 7 & 3 & 19 & 15 & 12 \\
\hline 6 & 18 & 24 & 34 & 14 & 18 & 11 & 6 & 15 \\
\hline 7 & 33 & 26 & & 9 & 12 & 18 & 11 & 16 \\
\hline 8 & 24 & 18 & 34 & 4 & 21 & 4 & 6 & 7 \\
\hline 9 & & & 36 & 13 & 15 & 19 & 20 & 11 \\
\hline 11 & & & 31 & 15 & 12 & 13 & 9 & 16 \\
\hline 13 & & & 33 & 16 & 11 & 13 & 13 & 12 \\
\hline 16 & 23 & 23 & 26 & 7 & 15 & 12 & 9 & \\
\hline 17 & 28 & 24 & & 6 & 10 & 9 & 9 & 5 \\
\hline 18 & 27 & 32 & 25 & 2 & 12 & 21 & 8 & 8 \\
\hline 19 & 23 & 29 & & 2 & 16 & 19 & 11 & 12 \\
\hline 20 & 31 & 26 & 34 & 3 & 20 & 16 & & \\
\hline 21 & & & 32 & 4 & 20 & 19 & 19 & 10 \\
\hline 23 & & & 35 & 9 & 10 & 10 & 4 & 9 \\
\hline 25 & & & 22 & 8 & 3 & 9 & 3 & 3 \\
\hline 27 & & & 38 & 7 & 6 & 8 & 8 & 9 \\
\hline 29 & & & 29 & 6 & & 15 & 12 & 4 \\
\hline 32 & & & 25 & & 9 & 14 & & \\
\hline 33 & 22 & & & & 18 & 8 & & \\
\hline 34 & 23 & & 30 & & 4 & 14 & & \\
\hline 35 & 22 & 15 & & & 10 & 9 & & \\
\hline 36 & 15 & 24 & 17 & & 8 & 9 & & \\
\hline 37 & 18 & 20 & & & 8 & 9 & & \\
\hline 38 & 19 & 21 & 25 & & 5 & 3 & & \\
\hline 39 & & 27 & & & 10 & 16 & & \\
\hline 40 & & 27 & 32 & & 8 & 9 & & \\
\hline 41 & & 34 & & & 14 & 19 & & \\
\hline 42 & & 30 & 33 & & 14 & 9 & & \\
\hline 43 & & & 33 & & 17 & 17 & & \\
\hline 45 & & & 20 & & 7 & 7 & & \\
\hline 47 & & & 19 & & 10 & 9 & & \\
\hline 49 & & 29 & 30 & & 23 & 20 & & \\
\hline 50 & & & 23 & & 12 & 12 & & \\
\hline 51 & & 18 & & & 19 & 17 & & \\
\hline 52 & & 12 & & & 10 & 9 & & \\
\hline 55 & & 22 & & & 10 & 14 & & \\
\hline 56 & & 22 & 29 & & 9 & 23 & & \\
\hline 57 & & 27 & & & 7 & 17 & & \\
\hline 58 & & & & & 6 & 15 & & \\
\hline 60 & & & & & 18 & 12 & & \\
\hline
\end{tabular}

In the fifties (Ursin), the Dogger Bank proper community was dominated by suspension feeding polychaetes such as Myriochele oculata and Owenia fusiformis, long-living bivalves such as Spisula subtruncata and Spisula elliptica, and ophiurids such as Ophiura albida and Acrocnida brachiata (Fig. 6; Table 13). During the eighties, however, this community was dominated by opportunistic, short-living polychaetes, bivalves and the ophiurid Amphiura filiformis. Birkett found the polychaetes Magelona spp., Scololepis 


\begin{tabular}{|c|c|}
\hline 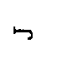 & 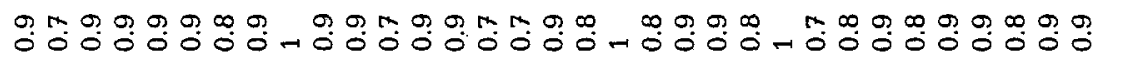 \\
\hline 工 & 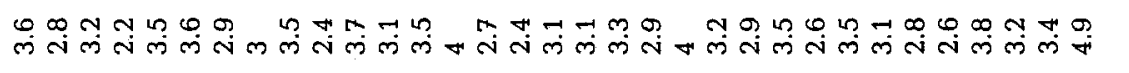 \\
\hline 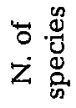 & 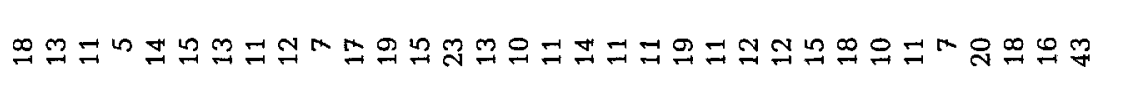 \\
\hline $\begin{array}{l}\text { 亗 } \\
\dot{\vec{n}} \\
\vec{n}\end{array}$ & 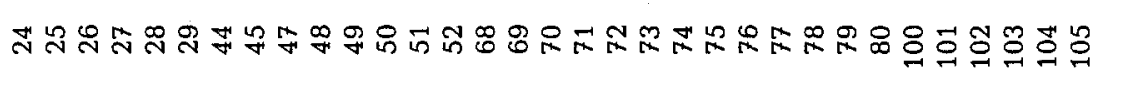 \\
\hline 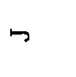 & 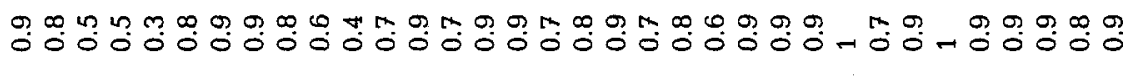 \\
\hline 工 & 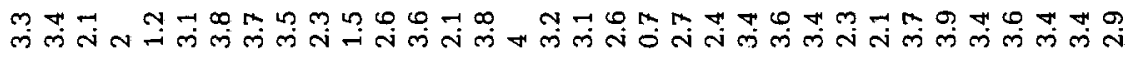 \\
\hline 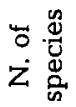 & 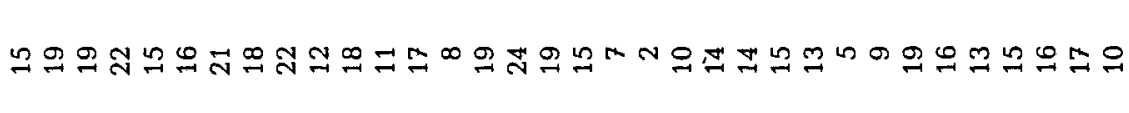 \\
\hline $\begin{array}{l}\dot{z} \\
\dot{\vec{d}} \\
\dot{\omega}\end{array}$ & ని \\
\hline$\checkmark$ & 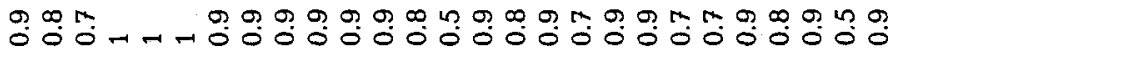 \\
\hline 宁 & 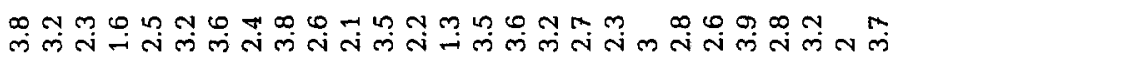 \\
\hline 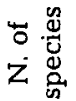 & 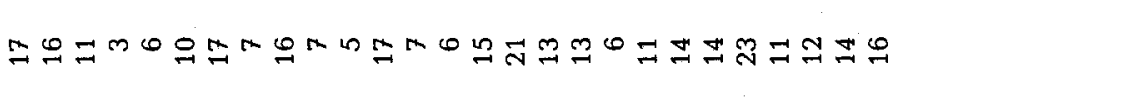 \\
\hline $\begin{array}{l}\vec{z} \\
\dot{\pi} \\
\vec{\omega}\end{array}$ & 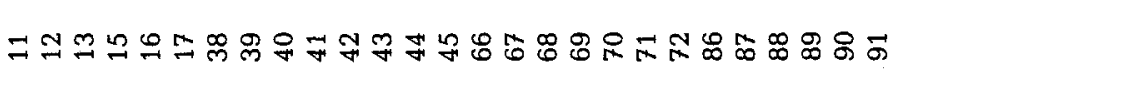 \\
\hline
\end{tabular}


Table 10. Mean diversities for 1985-1987 and 1950-1954 (Ursin)

\begin{tabular}{|c|c|c|c|c|c|c|c|c|}
\hline \multirow[t]{2}{*}{ Stat. } & \multicolumn{3}{|c|}{ Diversity $/ \mathrm{m}^{2}$} & \multicolumn{5}{|c|}{ Diversity $/ \mathrm{m}^{2}$} \\
\hline & 1985 & 1986 & 1987 & 1950 & 1951 & 1952 & 1953 & 1954 \\
\hline 5 & 3.4 & 4.1 & & 2.1 & 0.6 & 3.0 & 2.7 & 3.2 \\
\hline 6 & 3.2 & 3.5 & 3.4 & 3.6 & 3.6 & 2.8 & 2.0 & 1.7 \\
\hline 7 & 3.8 & 2.5 & & 2.9 & 1.3 & 1.6 & 2.8 & 3.8 \\
\hline 8 & 3.9 & 3.7 & 3.4 & 2.0 & 2.0 & 1.8 & 2.5 & 2.4 \\
\hline 9 & & & 4.0 & 3.0 & 3.3 & 2.3 & 1.6 & 1.4 \\
\hline 11 & & & 4.0 & 3.3 & 2.7 & 3.4 & 3.1 & 3.5 \\
\hline 13 & & & 3.4 & 3.2 & 2.4 & 2.0 & 3.3 & 1.3 \\
\hline 16 & 2.1 & 3.1 & 3.5 & 2.5 & 2.3 & 3.1 & 3.1 & \\
\hline 17 & 3.8 & 2.9 & & 2.4 & 3.1 & 2.2 & 2.9 & 2.2 \\
\hline 18 & 3.5 & 3.2 & 3.9 & 1.0 & 2.7 & 3.9 & 2.5 & 2.9 \\
\hline 19 & 3.3 & 3.0 & & 1.0 & 3.1 & 3.4 & 3.0 & 3.1 \\
\hline 20 & 3.5 & 3.8 & 3.6 & 1.4 & 3.5 & 3.4 & & \\
\hline 21 & & & 2.8 & 1.9 & 3.4 & 3.3 & 4.1 & 3.2 \\
\hline 23 & & & 3.2 & & 2.9 & 3.0 & 1.8 & 3.0 \\
\hline 25 & & & 4.0 & 2.9 & 1.5 & 2.8 & 0.2 & 1.6 \\
\hline 27 & & & 4.1 & 2.3 & 2.4 & 2.8 & 2.2 & 2.5 \\
\hline 29 & & & 2.9 & 1.7 & & 3.6 & 3.0 & 1.0 \\
\hline 32 & & & 3.0 & & 0.6 & 3.1 & & \\
\hline 33 & 2.8 & & & & 3.4 & 1.9 & & \\
\hline 34 & 3.4 & & 3.3 & & 1.8 & 3.3 & & \\
\hline 35 & 3.2 & 2.9 & & & 2.6 & 2.9 & & \\
\hline 36 & 3.1 & 3.4 & 3.1 & & 2.8 & 2.7 & & \\
\hline 37 & 3.2 & 3.1 & & & 2.9 & 2.8 & & \\
\hline 38 & 3.2 & 3.4 & 4.1 & & 1.7 & 1.5 & & \\
\hline 39 & & 3.7 & & & 2.6 & 3.1 & & \\
\hline 40 & & 3.5 & 3.3 & & 2.5 & 3.0 & & \\
\hline 41 & & 2.9 & & & 3.6 & & & \\
\hline 42 & & 2.8 & 3.0 & & 3.0 & 3.0 & & \\
\hline 43 & & & 1.6 & & 3.5 & 3.6 & & \\
\hline 45 & & & 3.2 & & 2.7 & 2.1 & & \\
\hline 47 & & & 3.4 & & 3.1 & 2.9 & & \\
\hline 49 & & 2.6 & 3.3 & & 3.3 & 3.6 & & \\
\hline 50 & & 3.5 & & & 2.4 & 1.6 & & \\
\hline 51 & & 2.2 & & & 2.8 & 3.0 & & \\
\hline 52 & & 3.0 & & & & 2.9 & & \\
\hline 55 & & 3.0 & & & 3.1 & 3.0 & & \\
\hline 56 & & 3.8 & 3.5 & & 2.6 & 3.6 & & \\
\hline 57 & & 3.8 & & & 1.6 & 2.7 & & \\
\hline 58 & & & 3.8 & & 1.6 & 2.4 & & \\
\hline 60 & & & 4.4 & & 3.6 & 3.2 & & \\
\hline
\end{tabular}

ciliata and Chaetozone setosa in higher abundances than Ursin did, in combination with generally low species numbers; thus, these species dominated his community. The remaining species composition is also different from the recent one.

In all the investigations, the community at the south-western border was dominated by Amphiura filiformis. In the recent community, more short-living species became dominant than in the fifties. 
Table 11. Mean evenness for 1985-1987 and 1950-1954 (Ursin)

\begin{tabular}{|c|c|c|c|c|c|c|c|c|}
\hline \multirow[t]{2}{*}{ Stat. } & \multicolumn{3}{|c|}{ Evenness $/ \mathrm{m}^{2}$} & \multicolumn{5}{|c|}{ Evenness $/ \mathrm{m}^{2}$} \\
\hline & 1985 & 1986 & 1987 & 1950 & 1951 & 1952 & 1953 & 1954 \\
\hline 5 & 0.7 & 0.8 & & 0.8 & 0.4 & 0.7 & 0.9 & 0.9 \\
\hline 6 & 0.8 & 0.8 & 0.7 & 0.9 & 0.9 & 0.8 & 0.8 & 0.4 \\
\hline 7 & 0.8 & 0.5 & & 0.9 & 0.4 & 0.4 & 0.8 & 1.0 \\
\hline 8 & 0.8 & 0.9 & 0.7 & 1.0 & 0.4 & 0.9 & 1.0 & 0.9 \\
\hline 9 & & & 0.8 & 0.8 & 0.9 & 0.5 & 0.4 & 0.4 \\
\hline 11 & & & 0.8 & 0.9 & 0.8 & 0.9 & 1.0 & 0.9 \\
\hline 13 & & & 0.7 & 0.8 & 0.7 & 0.5 & 0.9 & 0.4 \\
\hline 16 & 0.5 & 0.7 & 0.7 & 0.9 & 0.6 & 0.9 & 1.0 & 0.3 \\
\hline 17 & 0.8 & 0.6 & & 0.9 & 0.9 & 0.7 & 0.9 & 0.9 \\
\hline 18 & 0.7 & 0.6 & 0.8 & 1.0 & 0.7 & 0.9 & 0.9 & 1.0 \\
\hline 19 & 0.7 & 0.6 & & 1.0 & 0.8 & 0.8 & 0.9 & 0.9 \\
\hline 20 & 0.8 & 0.8 & 0.7 & 0.9 & 0.8 & 0.9 & & \\
\hline 21 & & & 0.6 & 1.0 & 0.8 & 0.8 & 1.0 & 1.0 \\
\hline 23 & & & 0.6 & 1.0 & 0.9 & 0.9 & 0.9 & 1.0 \\
\hline 25 & & & 0.9 & 1.0 & 1.0 & 0.9 & 0.1 & 1.0 \\
\hline 27 & & & 0.8 & 0.8 & 0.9 & 0.9 & 0.7 & 0.8 \\
\hline 29 & & & 0.6 & 0.7 & & 0.9 & 0.9 & 1.0 \\
\hline 32 & & & 0.7 & & 0.2 & 0.8 & & \\
\hline 33 & 0.6 & & & & 0.8 & 0.6 & & \\
\hline 34 & 0.8 & & 0.7 & & 0.9 & 0.9 & & \\
\hline 35 & 0.7 & 0.8 & & & 0.8 & 0.9 & & \\
\hline 36 & 0.8 & 0.8 & 0.8 & & 0.9 & 0.9 & & \\
\hline 37 & 0.8 & 0.7 & & & 1.0 & 0.9 & & \\
\hline 38 & 0.8 & 0.8 & 0.9 & & 0.7 & 0.9 & & \\
\hline 39 & & 0.8 & & & 0.8 & 0.8 & & \\
\hline 40 & & 0.7 & 0.7 & & 0.8 & 1.0 & & \\
\hline 41 & & 0.6 & & & 1.0 & 0.9 & & \\
\hline 42 & & 0.6 & 0.6 & & 0.8 & 1.0 & & \\
\hline 43 & & & 0.3 & & 0.9 & 0.9 & & \\
\hline 45 & & & 0.8 & & 1.0 & 0.7 & & \\
\hline 47 & & & 0.8 & & 0.9 & 0.9 & & \\
\hline 49 & & 0.5 & 0.7 & & 0.7 & 0.8 & & \\
\hline 50 & & 0.8 & & & 0.7 & 0.5 & & \\
\hline 51. & & 0.5 & & & 0.7 & 0.7 & & \\
\hline 52 & & 0.8 & & & & 0.9 & & \\
\hline 55 & & 0.7 & & & 0.9 & 0.8 & & \\
\hline 56 & & 0.8 & 0.7 & & 0.8 & 0.8 & & \\
\hline 57 & & 0.8 & & & 0.6 & 0.7 & & \\
\hline 58 & & & 0.7 & & 0.6 & 0.6 & & \\
\hline 60 & & & 0.8 & & 0.9 & 0.9 & & \\
\hline
\end{tabular}

Only in 1985-87 was a separate community observed to occur in the northeastern part that was characterized by the presence of the polychaetes Ophelia limacina and Goniada maculata, species that were predominant in the earlier investigations on the whole Dogger Bank. 


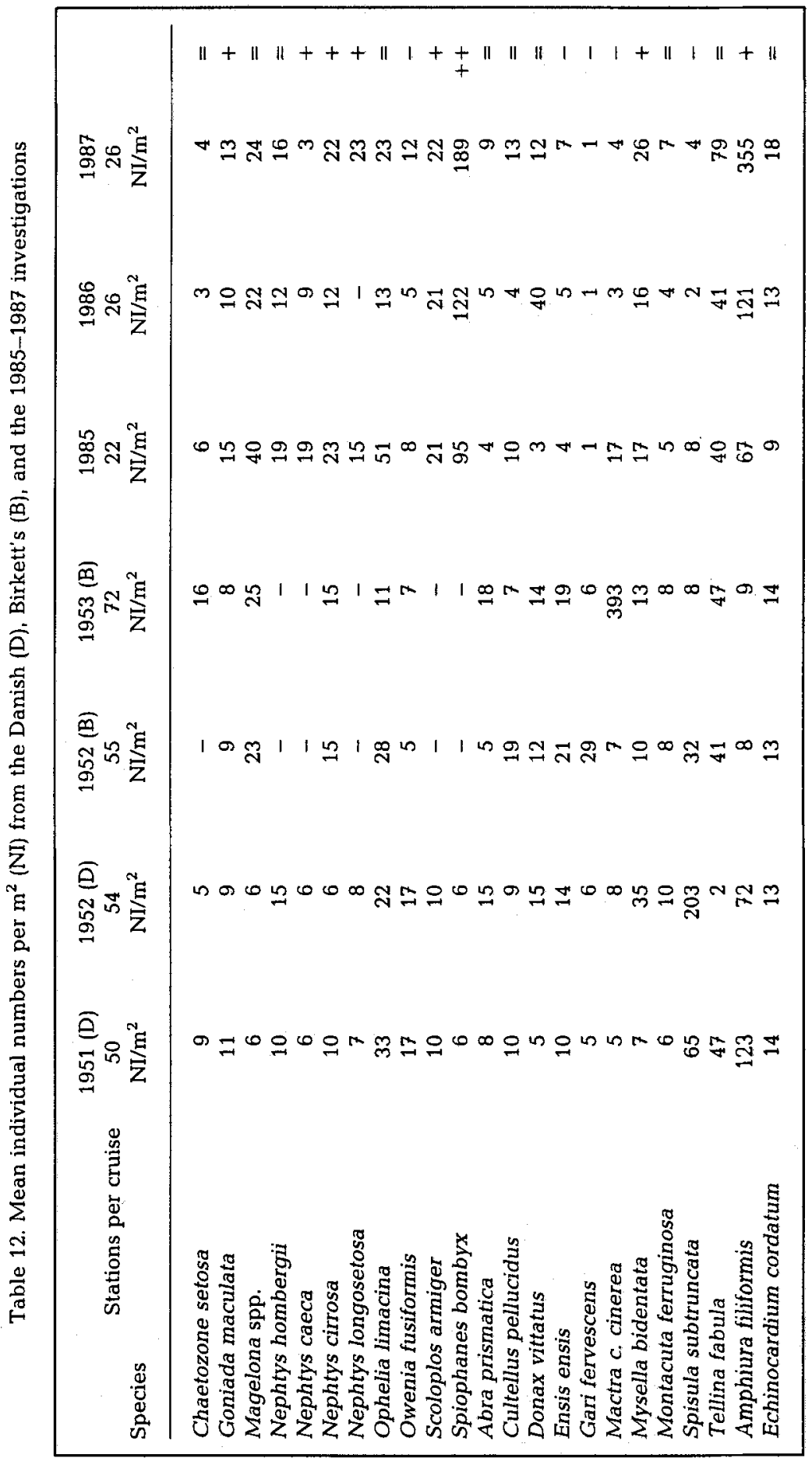



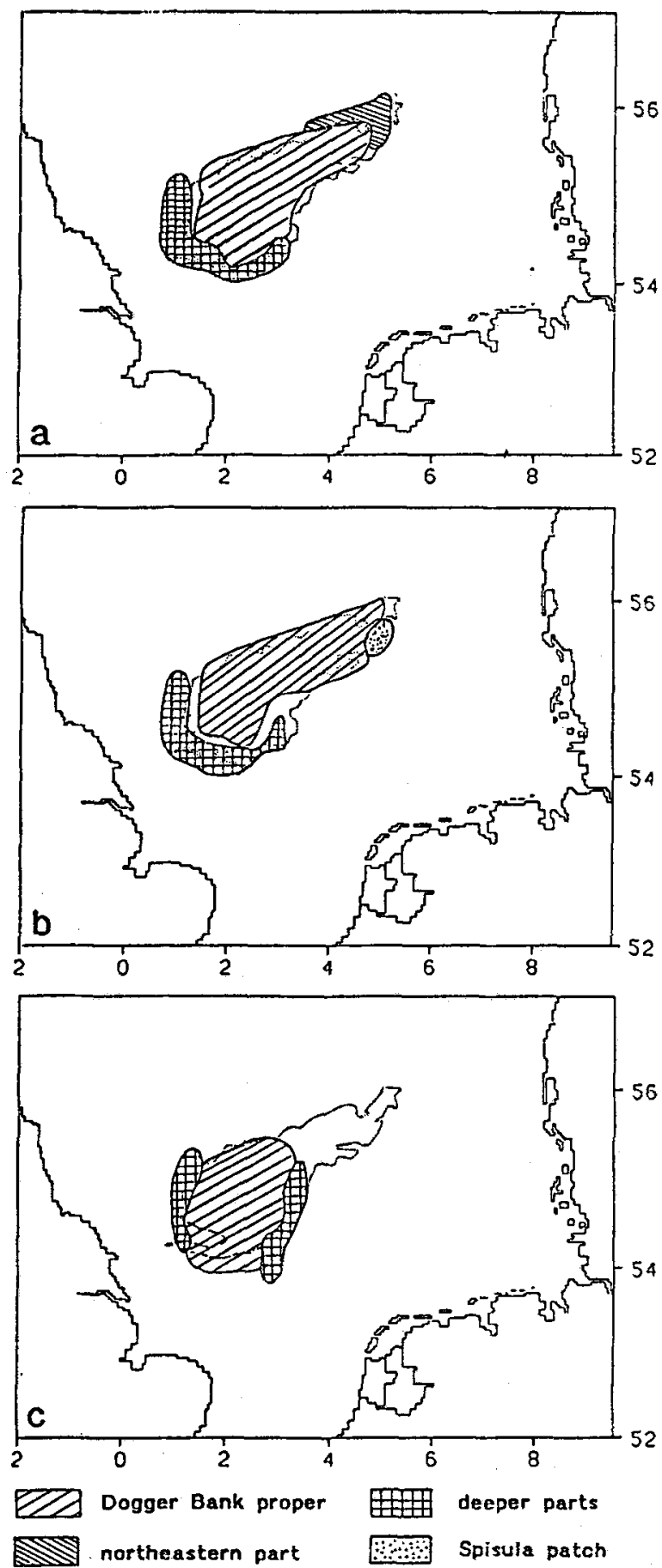

Fig. 6. Macrofauna communities in (a) 1985-87, (b) 1951-52 after Ursin and (c) 1953-54 after Birkett 
Table 13. Ten dominant species within the communities in the Dogger Bank area

\begin{tabular}{|c|c|c|}
\hline $1985-1987$ & 1951-1952 (Danish) & 1953-1954 (Birkett) \\
\hline Dogger Bank proper & Dogger Bank proper & Dogger Bank proper \\
\hline $\begin{array}{l}\text { Spiophanes bombyx } \\
\text { Paraonis fulgens } \\
\text { Amphiura filiformis } \\
\text { Nucula tenuis } \\
\text { juv. Ophiuroidea } \\
\text { Phoronis spp. } \\
\text { Tellina fabula } \\
\text { Scoloplos armiger } \\
\text { Magelona spp. } \\
\text { Donax vittatus }\end{array}$ & $\begin{array}{l}\text { Myriochele oculata } \\
\text { Acrocnida brachiata } \\
\text { Tellina fabula } \\
\text { Ophiura albida } \\
\text { Ophelia limacina } \\
\text { Spisula subtruncata } \\
\text { Echinocyamus pusillus } \\
\text { Owenia fusiformis } \\
\text { Spisula elliptica } \\
\text { Goniada maculata }\end{array}$ & $\begin{array}{l}\text { Magelona spp. } \\
\text { Scolelepis ciliata } \\
\text { Chaetozone setosa } \\
\text { Nepthys spp. } \\
\text { Glycinde nordmanni } \\
\text { Ophelia limacina } \\
\text { Eteone lactea } \\
\text { Anaitides subulifera } \\
\text { Myriochele oculata } \\
\text { Anaitides maculata }\end{array}$ \\
\hline Deeper Parts & Deeper Parts & Deeper Parts \\
\hline $\begin{array}{l}\text { Amphiura filiformis } \\
\text { juv. Amphiura } \\
\text { Montacuta bidentata } \\
\text { Pholoe minuta } \\
\text { juv. Ophiuroidea } \\
\text { Phoronis spp. } \\
\text { Spiophanes bombyx } \\
\text { Thyasira flexuosa } \\
\text { Nucula nitida } \\
\text { Nucula tenuis }\end{array}$ & $\begin{array}{l}\text { Amphiura filiformis } \\
\text { Acrocnida brachiata } \\
\text { Amphiura chiajei } \\
\text { Lumbrinereis spp. } \\
\text { Pectinaria auricoma } \\
\text { Echinocardium cordatum } \\
\text { Montacuta bidentata } \\
\text { Tellina fabula } \\
\text { Nucula nitida } \\
\text { Echinocyamus ousillus }\end{array}$ & $\begin{array}{l}\text { Magelona spp. } \\
\text { Scolelepis ciliata } \\
\text { Nephtys spp. } \\
\text { Myniochele oculata } \\
\text { Pectinaria auricoma } \\
\text { Glycinde nordmanni } \\
\text { Eumida sanguinea } \\
\text { Eteona lactea } \\
\text { Ophelia limacina } \\
\text { Owenia fusiformis }\end{array}$ \\
\hline \multicolumn{3}{|l|}{ Northeastern part } \\
\hline $\begin{array}{l}\text { Spiophanes bombyx } \\
\text { Ophelia limacina } \\
\text { juv. Ophiuroidea } \\
\text { Scoloplos armiger } \\
\text { Abra prismatica } \\
\text { Phoronis spp. } \\
\text { Goniada maculata } \\
\text { Myriochele oculata } \\
\text { Thracia phaeseolina } \\
\text { Amphiura filiformis }\end{array}$ & & \\
\hline
\end{tabular}

\section{Biomass}

In 1987, the total biomass in most of the nautical squares was 2.5 to 8 times higher than in 1950-54 (Fig. 7); however, a reduction in biomass of $30 \%$ was found for the northeastern squares. Polychaetes doubled their biomass within the last 30 years. The biomass of echinoderms increased 3 to 5 times on the central Dogger Bank, and 7 to 15 times in the southern nautical squares. In the northeastern squares, it decreased as their 
total biomass did. Mollusca biomass increased 2- to 5-fold, except in the northeastern squares where it decreased by about $30 \%$.

\section{Similarities between stations}

A mean similarity of only $17.4 \%$ between Ursin's and the recent data (Table 14) for the whole Dogger Bank was calculated by the presence/absence of species (Greig-Smith, 1964). Similarities per species between the present and Ursin's data set varied from 7 to $23 \%$; between the present and Birkett's set from 9 to $13 \%$ (Figs 8,9 ).

\section{Abundance-Biomass-Comparison curves}

Although no biomass data per species exist for the fifties, the ABC-method was applied to assess the amount of biological disturbance in the communities of the Dogger Bank during the eighties. Figures 10 and 11 give the abundance $(A)$ and biomass $(B)$ per species for several stations in 1985 and 1986. Most of the curves indicate undisturbed communities, but in both years the curves for stations 16 and 18 from the northeastern Dogger Bank are close together indicating moderately disturbed communities. The biomass at stations 35 to 52 is dominated by the sea-urchin Echinocardium cordatum.

\section{DISCUSSION}

\section{Methodological comparison}

The different grab weights had no influence on the comparability of the data sets (Fig. 4; Tables 5,6), nor did the different mesh sizes produce any differences in the species numbers, diversity, evenness and species composition (Fig. 5; Tables 5, 6). Thus, the main difference observed was the different number of small individuals, and this was due to the loss of individuals through the larger mesh size used in 1950-54. As the percentage of loss was estimated and the data of 1985-87 were first converted with this percentage (Table 7) and then used for the long-term comparison, the comparability of the data sets is guaranteed.

\section{Long-term comparison}

The changes found between the macrofauna communities of $1950-54$ and 1985-87 can be described as follows:

- higher species numbers

- diversity decline

- increase of opportunistic, short-living species

- decrease of long-living bivalves

- 2.5 to 8-fold increase in biomass

- low similarity between stations from the fifties and the eighties

The question arose whether these changes have been caused by natural changes in the environment or by anthropogenic impact?

\section{Natural changes}

Changing water temperature, current systems and weather conditions may play a role, but North Sea surface temperatures from 1902-54 and from 1971-80 (Tomczak \& 

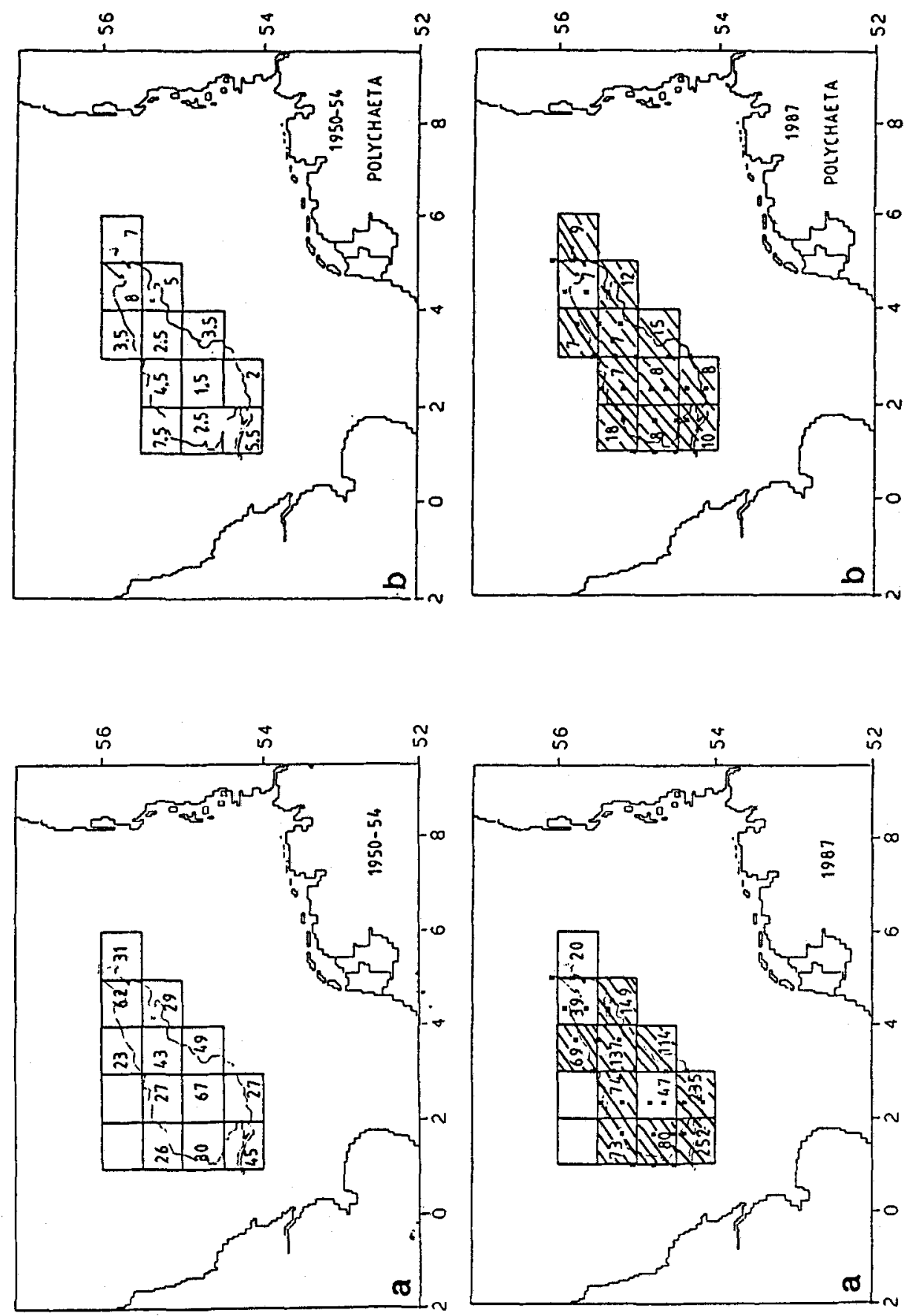

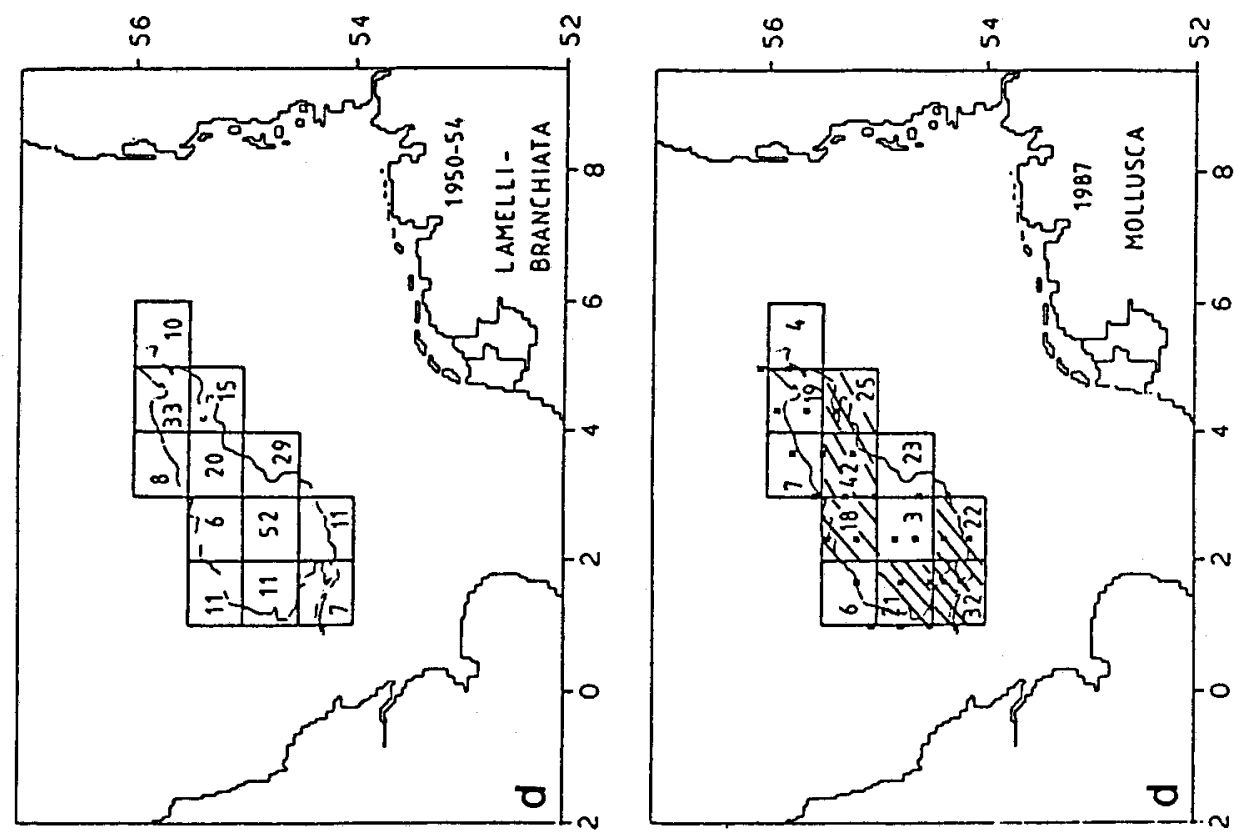

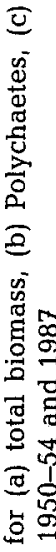

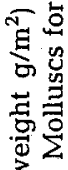
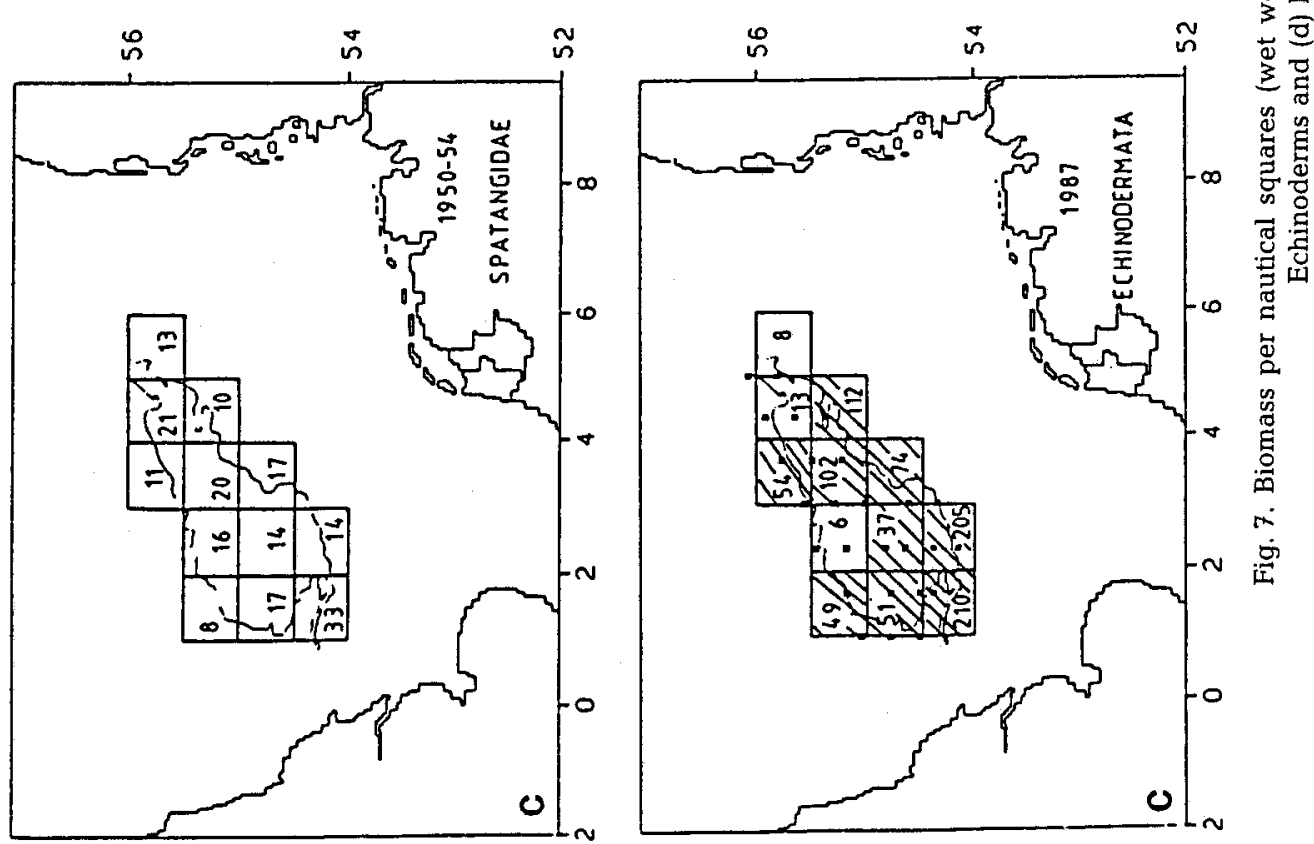
Table 14. Similarities between stations from 1985-1987 and 1951-1952 (Ursin) after Greig-Smith (1964)

\begin{tabular}{|c|c|c|c|c|c|c|c|c|c|}
\hline \multirow[t]{2}{*}{ St. } & \multicolumn{3}{|c|}{1985} & \multicolumn{3}{|c|}{1951} & \multicolumn{3}{|c|}{1952} \\
\hline & & $6-20$ & $31-40$ & & & $31-40$ & $6-$ & & $31-40$ \\
\hline $\begin{array}{c}1985 \\
6-20 \\
31-40\end{array}$ & & 41.8 & 33.3 & & & 18.1 & 18 & & 15.7 \\
\hline $\begin{array}{c}1951 \\
6-20 \\
31-40\end{array}$ & & & & & & 18.4 & & & \\
\hline $\begin{array}{c}1952 \\
6-20 \\
31-40\end{array}$ & & & & & & & 26 & & 20.1 \\
\hline St. & 6-20 & $\begin{array}{c}1986 \\
35-50\end{array}$ & $51-57$ & $6-20$ & $\begin{array}{c}1951 \\
35-50\end{array}$ & $51-57$ & $6-20$ & $\begin{array}{c}1952 \\
35-50\end{array}$ & $51-57$ \\
\hline $\begin{array}{r}1986 \\
6-20 \\
35-50 \\
51-57\end{array}$ & 49.9 & 37.6 & 33.6 & 22.4 & 15.5 & 12.0 & 19.8 & 16.7 & 21.1 \\
\hline $\begin{array}{c}1951 \\
6-20 \\
35-50 \\
51-57\end{array}$ & & & & 28.3 & 20.0 & 19.6 & & & \\
\hline $\begin{array}{c}1952 \\
6-20 \\
35-50 \\
51-57\end{array}$ & & & & & & & 26.7 & 18.2 & 23.1 \\
\hline St. & $6-20$ & $\begin{array}{c}1987 \\
21-40\end{array}$ & $42-60$ & $6-20$ & $\begin{array}{c}1951 \\
21-40\end{array}$ & $42-60$ & $6-20$ & $\begin{array}{c}1952 \\
21-40\end{array}$ & $42-60$ \\
\hline $\begin{array}{r}1987 \\
6-20 \\
21-40 \\
42-60\end{array}$ & 48.1 & 40.0 & 33.9 & 23.5 & 12.3 & 16.6 & 20.8 & 14.9 & 20.0 \\
\hline $\begin{array}{r}1951 \\
6-20 \\
21-40 \\
42-60\end{array}$ & & & & 32.1 & 11.4 & 17.0 & & & \\
\hline $\begin{array}{r}1952 \\
6-20 \\
21-40 \\
42-60\end{array}$ & & & & & & & 28.0 & 12.8 & 20.4 \\
\hline
\end{tabular}


STAT. $5 \cdot 20$

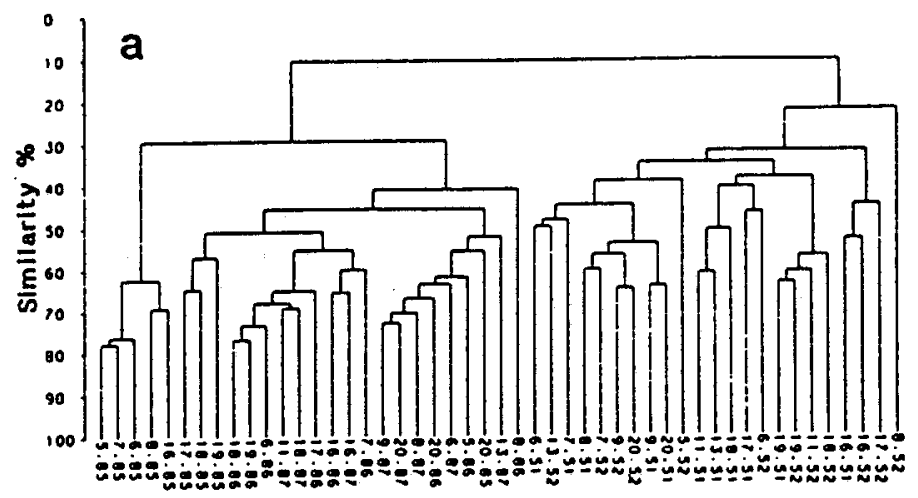

STAT. $21-40$

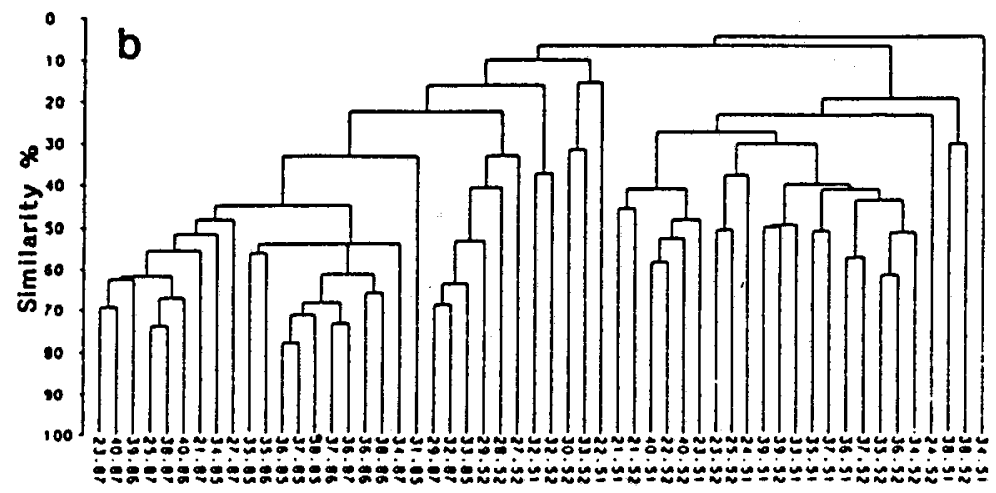

STAT. 41-60

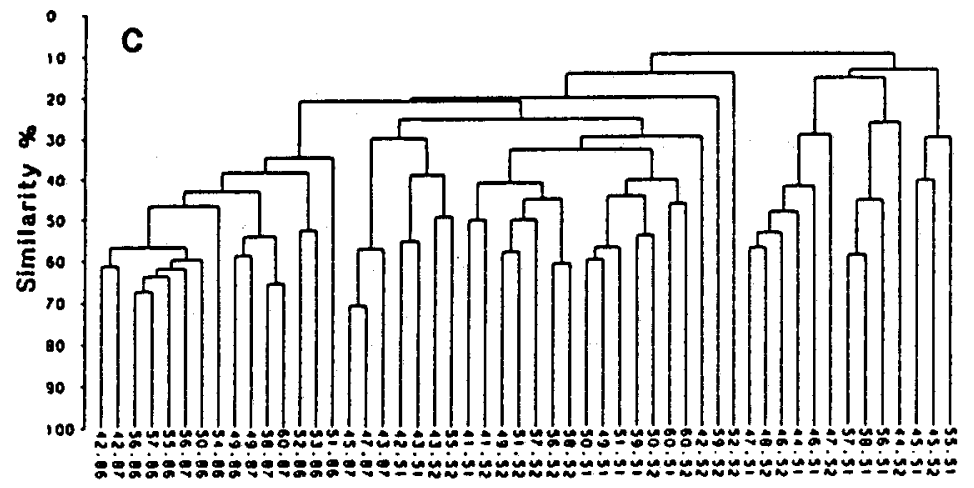

Fig. 8. Similarities between the stations of $1985-87$ and 1951-52 (Ursin) 


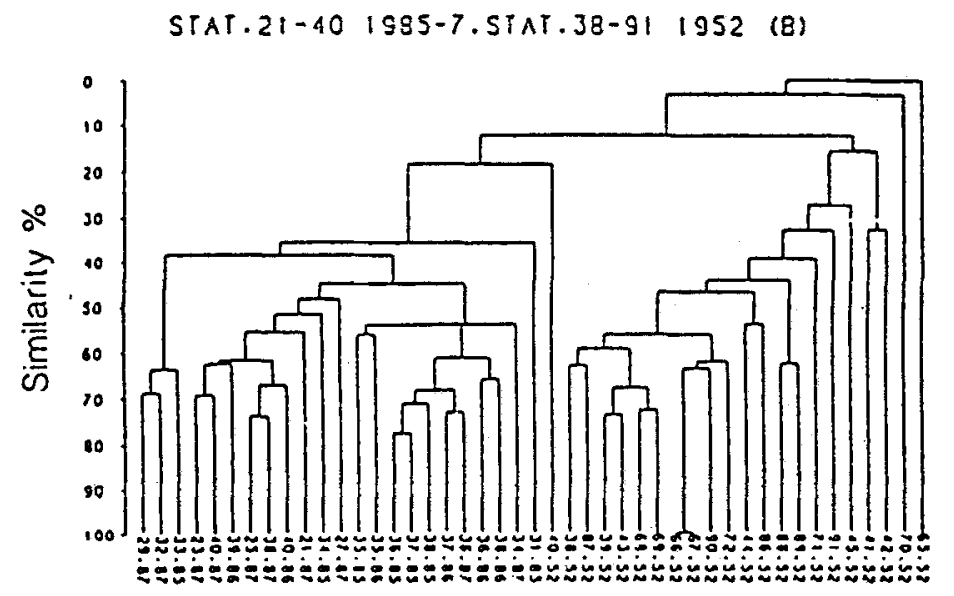

STAT.41-60 1995-7. STAT.11-18.38.391952

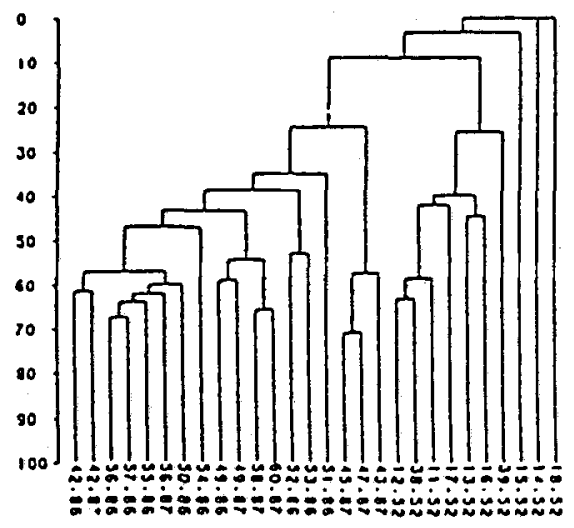

Fig. 9. Similarities between the stations of 1985-87 and 1952 (Birkett)

Goedecke, 1962; Becker et al., 1986) do not show any significant increase. Taylor \& Stephens (1983) mentioned a small increase of surface temperatures in winter and spring in the Southern Bight of $0.3^{\circ} \mathrm{C}$ from 1961 to 1976 . However, no data for bottom temperatures are available, and their impact on changes in the benthos may be neglected. No information on changing current activities in the Dogger Bank area is available. Wind data (Seewetteramt Hamburg, pers. comm.) do not show higher frequencies of heavy storms during the fifties than during the eighties.

Besides natural environmental changes, anthropogenic influences on the macrofauna communities of the Dogger Bank have to be considered.

\section{Anthropogenic impact}

Purdom \& Garrod (1990) indicated an increase in fishery for haddock, cod and plaice on the Dogger Bank since 1950. On the other hand, well-known fisheries biologists such 

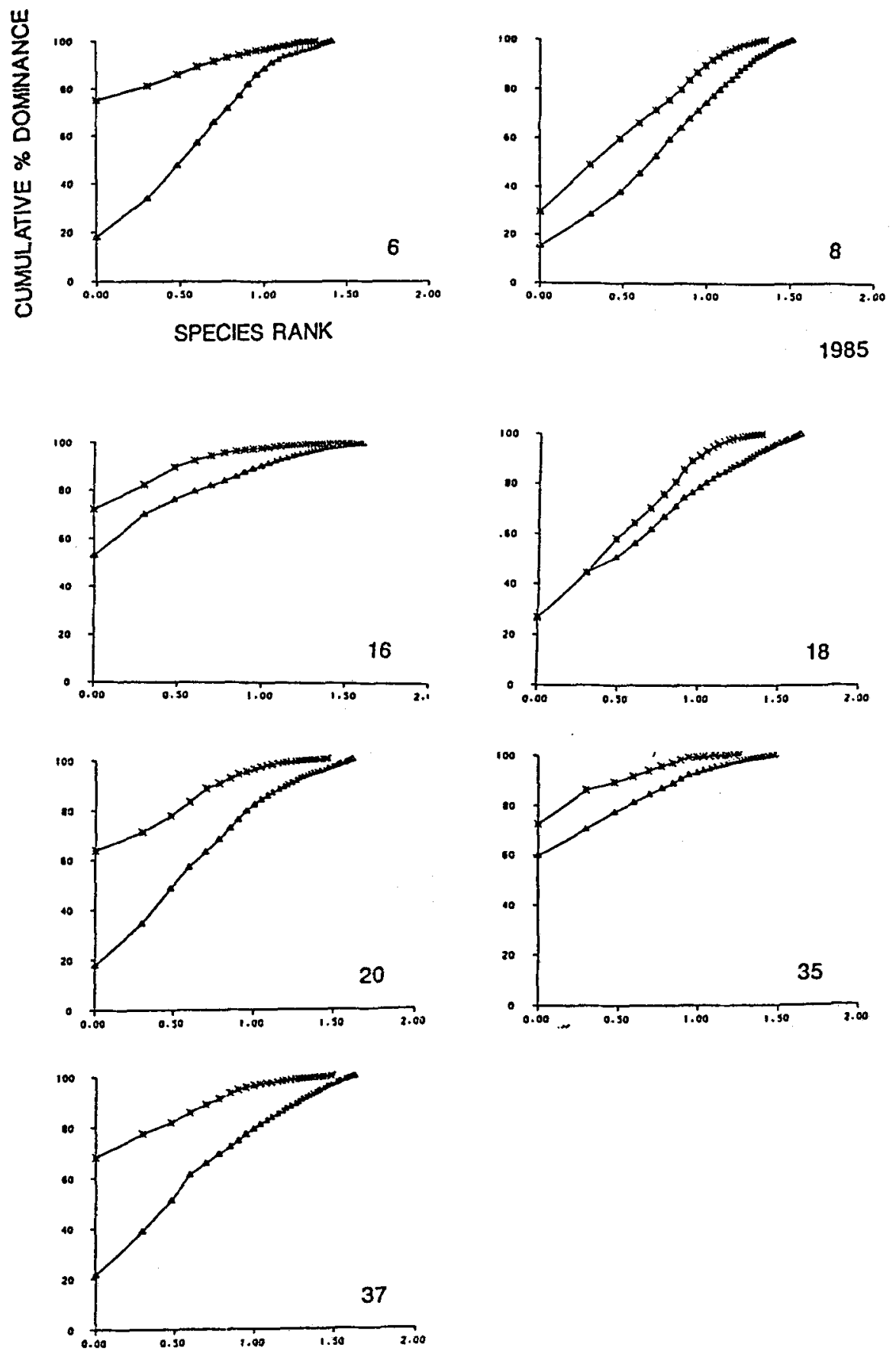

Fig. 10. ABC curves for the few stations of April/May 1985. $\Delta=$ abundance, $^{*}=$ biomass 
Ingrid Kröncke
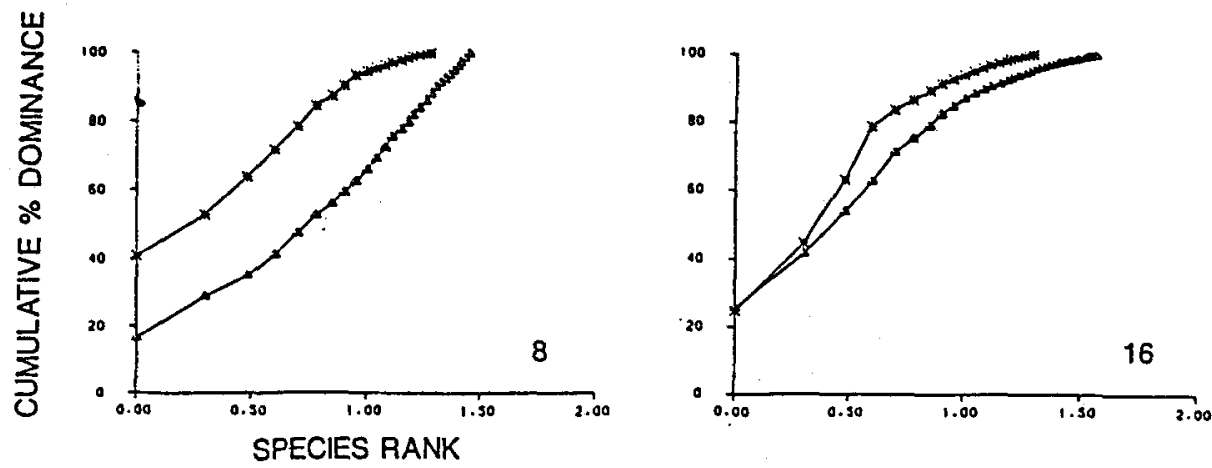

1986
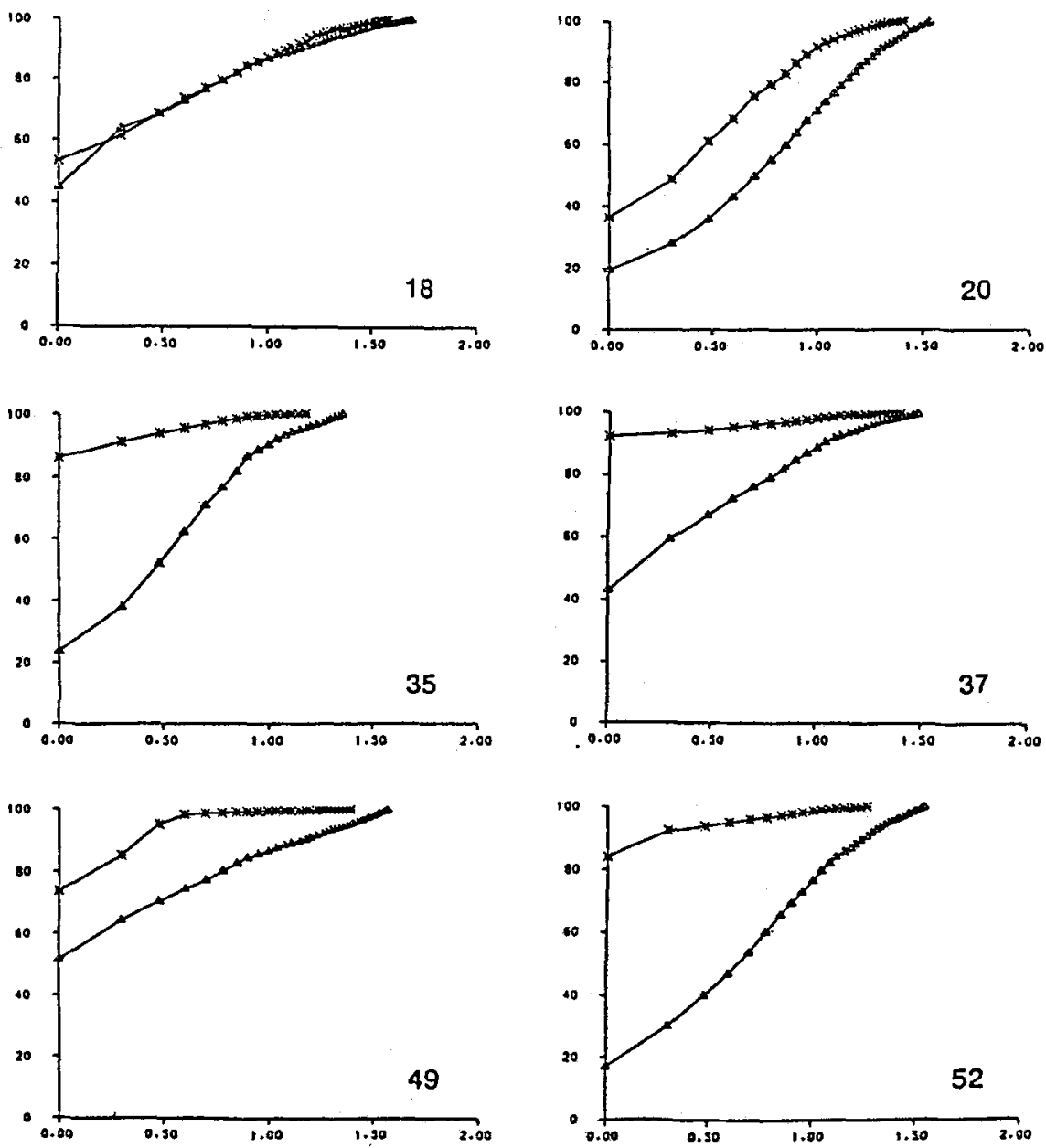

Fig. 11. ABC curves for the few stations of April/May 1986. $\Delta=$ abundance, ${ }^{*}=$ biomass 
as Rauck, Daan and Pope (pers. comm.) think the Dogger Bank has been unimportant for commercial fisheries for the past 10 years, and the above mentioned increase is negligible in relation to the whole North Sea. Sand-eel fishery takes place in spring around the Dogger Bank with light gear that should not damage the sea floor (Popp Madsen, pers. comm.). The stable distribution of the sea-urchin Echinocardium cordatum on the whole Dogger Bank in comparison with the former investigations seems to support the idea that damage by fisheries is an unimportant factor with regard to benthic community changes since this species is severely suffering under fishery pressure in other areas (Redant, 1987).

Concerning other anthropogenic impacts, the changes in the macrofauna communities of the Dogger Bank generally fit well into the model given .by Pearson \& Rosenberg (1978) for communities under increasing eutrophication of the environment. The changes are confirmed by other investigations as well. From the fifties to the eighties the number of species increased from 12 and 14 to 23 and 29 per $0.2 \mathrm{~m}^{2}$, which is a 100 to $150 \%$ increase (Tables 8, 9). Pearson \& Rosenberg (1978) described a general increase of species number under increasing eutrophication, which was also found by Rosenberg \& Möller (1979) and Riesen \& Reise (1982). The extreme increase in the number of species should have caused a higher rise in diversity than that calculated (Tables 9, 10). The lower evenness in 1985-87 (Tables 9, 11) indicates a dominance of less species during the eighties than during the fifties, which explains the rather low increase in diversity. Polychaete species such as Spiophanes bombyx and Scoloplos armiger which increased in numbers from 1950-54 to 1985-87 (Table 12), are said to be opportunistic and tolerant of bad environmental conditions (Pearson \& Rosenberg, 1978; Rachor, 1982; Reise, 1982; Pearson et al., 1983; von Westernhagen et al., 1986). The increase of predators such as Nephtys hombergii and Nephtys caeca may be due to the increase of small polychaete species, for example Scoloplos armiger (Table 12). As Schubert \& Reise (1986) and Beukema (1987) have shown, N. hombergii feeds mainly on S. armiger.

The ophiurid Amphiura filiformis was found in increasing densities during several investigations related to enrichment of organic matter (Rosenberg \& Möller, 1979; Pearson et al., 1985, 1986; Rosenberg et al., 1987). Duineveld et al. (1987) mentioned a drastic increase of this species in the southern North Sea due to enrichment of organic matter. For the bivalve species a recent dominance of small, short-living species is obvious. They represented r-selective species that are known to be more tolerant of changing environmental conditions. Species such as Ensis ensis, Mactra c. cinerea and Spisula subtruncata which can become quite old have been drastically reduced (Table 12). No patch as during the fifties (Petersen, 1977; Birkett, unpubl. data in Kröncke, 1991) could be found and all specimens found measured a few millimetres only.

The total benthic biomass $\left(\mathrm{g} / \mathrm{m}^{2}\right.$ wet weight $)$ in most of the nautical squares on the Dogger Bank was 2.5 to 8 times higher in 1987 than in 1951-52 (Fig. 7). Increasing biomass is often described as resulting from the enrichment of organic matter in the environment, e.g. investigations in the Skagerrak and Baltic Sea by Cederwall \& Elmgren (1980) and Rosenberg et al. (1987), and in the German Bight by Rachor (1990). The reduced biomass of about $30 \%$ in 1987 in the northeastern part of the Dogger Bank is mainly due to the lack of bivalves, i.e. to the lack of the Spisula patch Petersen (1977) found in the fifties, but even polychaetes and echinoderms show decreased weights.

Calculated similarities between the stations of the fifties and the eighties of 7 to $23 \%$ 
(Figs 8, 9; Table 14) are lower than those found by Pearson et al. (1985) and Rosenberg et al. (1987) with $30 \%$ and $27 \%$, respectively, when comparing their recent data from Kattegat and Skagerrak with Petersen's from 1911-12. The cluster analyses of all data sets revealed two sediment-dependent communities (Fig. 6; Table 12): one on the Dogger Bank proper in fine sands with shells, and another one in the deeper boundary parts on muddy fine sands. The community in the deeper parts was dominated by Amphiura filiformis during all investigations, but during the eighties more short-living species were found. There was a clear shift in dominance to short-living, deposit-feeding species in the community on the Dogger Bank proper. This confirms that communities on muddy sands that have a higher content of organic matter show less effects following possible eutrophication than those on fine sands with a lower content of organic matter.

An assessment of the amount of biological disturbance by the $A B C$-method by Warwick (1986) revealed that only the communities from the northeastern part of the Dogger Bank seem to be moderately disturbed (Figs 10,11). The shape of the curves for the central and western stations is characteristic of unpolluted communities on muddy sands (Warwick et al., 1987). As the sediment of the central Dogger Bank is sand with only a small amount of mud, the high biomass curve indicates a better food resource than is otherwise typical for sand areas.

Evidence of increasing eutrophication as is available for the coastal parts of the North Sea where increasing nutrient concentrations, increasing phytoplankton biomass (Gerlach, 1984; Hickel et al., 1989; Radach \& Bohle-Carbonell, 1990) and corresponding macrofauna changes (Rachor, 1990) have been reported, is not available for the Dogger Bank area. Nevertheless, it is a region of high phytoplankton production during winter (Brockmann \& Wegner, 1985; Richardson \& Olsen, 1987). As Duineveld et al. (1987) discovered that adjacent areas of the Dogger Bank are also enriched, there is evidence that the changes in the macrofauna communities might be due to increasing eutrophication of the Dogger Bank. As this area is influenced by residual currents (Hainbucher et al., 1986), rather coarse sediments are found. On the other hand, however, it is a region of high production due to continual sedimentation and resuspension.

Another anthropogenic impact might be the increasing pollution of the central North Sea. In contrast to the prevailing opinion of undisturbed offshore regions, highest concentrations of lead and cadmium were found in the fine fraction $(<20 \mu \mathrm{m})$ of sediments (Albrecht 1987; Irion \& Müller, 1987; Kersten \& Klatt, 1988), in macrofauna species (Kröncke, 1987; Karbe et al., 1988; Everaarts \& Fischer, 1989) and in dab (Limanda limanda) (Claussen, 1988) on the Dogger Bank compared with the concentrations found in the German Bight and Danish coastal waters. Irion \& Müller (1990) could show by dating sediment cores that on the eastern part and south of the Dogger Bank within the uppermost $10 \mathrm{~cm}$ depth there is an increase in lead concentration of $100-150 \%$. Kersten \& Kröncke (1992) give evidence that the fine fraction $(<20 \mu \mathrm{m})$ of the Dogger Bank sediments are twice as toxic as those from the German Bight. Some macrofaunal species prefer to feed on particles smaller than $20 \mu \mathrm{m}$ - highly contaminated particles Brown (1986) -, which might prevent long-living bivalve species from becoming old and large, for these species are known to accumulate, for example, large amounts of cadmium (Ray, 1984).

At the moment, it is impossible to say which factor or which combination of factors might have caused the changes in the Dogger Bank benthic communities. All that can be 
said is that even in offshore populations long-term changes can be detected. This fact contradicts the prevailing opinion of unaffected offshore communities in contrast to often highly affected nearshore ones.

Acknowledgements. I am grateful to Prof. H. Thiel for supervising my thesis, to Prof. H.-P. Bulnheim for the opportunity to work at the Biologische Anstalt Helgoland (BAH), Hamburg, to the late Prof. E. T. Degens, and to Dr. S. Kempe for financial support within the TOSCH-project and to Dr. V. Dethlefsen for suggesting the long-term comparison and providing berths on board FRV "Anton Dohrn", FRV "Walther Herwig" and RC "Solea". Thanks are due as well to Dr. L. Birkett and the Ministry of Agriculture, Fisheries and Food, Lowestoft; for putting the whole unpublished data-set at my disposal, to Prof. G. Høpner Petersen for making the original bivalve data available to me, to Prof. E. Dahl for re-working the Amphipoda data from 1950-54 and to Dr. K. Figge for grain size analysis. Many thanks to Dr. W. Greve (BAH) and F. Reiners (BAH) for the possibility to perform the plots with MABIS software. I thank Dr. R. Knust, Dr. A. Künitzer, J. Berg and many other people including the crews of all research vessels for their help on board. Thanks to K. Kröncke, T. Knütel and S. Asmussen for their help in sorting samples, and Dr. E. Rachor for critically reading the manuscript. The subject of this paper was financed by the German Ministry of Research and Technology, BMFTproject "Biogeochemistry and the distribution of suspended matter in the North Sea and implication to Fisheries Biology" (MFU 0543-8).

\section{LITERATURE CITED}

Albrecht, H., 1987. Sediment studies in the German Bight and adjacent areas of the North Sea. ICES coop. Res. Rep. 150, 112-131.

Becker, G. A., Frey, H. \& Wegner, G., 1986. Atlas der Temperatur an der Oberfläche der Nordsee. Dt. hydrogr. Z. (Erg.-H. B) 17, 1-127.

Beukema, J. J., 1987. Influence of the predatory polychaete Nephty's hombergii on the abundance of other polychaetes. - Mar. Ecol. Prog. Ser. 40, 95-101.

Brockmann, U. N. \& Wegner, G., 1985. Hydrography, nutrient and chlorophyll distribution in the North Sea in February 1984. - Arch. FischWiss. 36, 27-45.

Brown, S. L., 1986. Feces of intertidal benthic invertebrates: influence of particle selection in feeding on trace element concentration. - Mar. Ecol. Prog. Ser. 28, 219-231.

Cederwall, H. \& Elmgren, R., 1980. Biomass increase of benthic macrofauna demonstrates eutrophication of the Baltic Sea. - Ophelia (Suppl.) 1, 287-304.

Claussen, T., 1988. Characteristic levels and spatial distribution of trace metals in flatfish (dab, Limanda limanda) from the German Bight and the Southern North Sea. - Mitt. geol.-paläont. Inst. Hamburg (SCOPE/UNEP Sonderbd) 65, 467-496.

Duineveld, G. C. A., Künitzer, A. \& Heyman, R. P., 1987. Amphiura filiformis (Ophiuroidea: Echinodermata) in the North Sea. Distribution, present and former abundance and size composition. - Neth. J. Sea Res. 21, 317-329.

Everaarts, J. M. \& Fischer, C. V., 1989. Microcontaminants in surface sediments and macrobenthic invertebrates of the North Sea. - NIOZ-Rapp. 1989-6, 1-44.

Gerlach, S. A., 1984. Oxygen depletion 1980-1983 in coastal waters of the Federal Republic of Germany. - Ber. Inst. Meeresk. Kiel 130, 1-87.

Greig-Smith, P., 1964. Quantitative plant ecology. Butterworths, London, $256 \mathrm{pp}$.

Hainbucher, D., Backhaus, J. O. \& Pohlmann, T., 1986. Atlas of climatological and actual circulation patterns in the North Sea and adjacent shelf regions. 1969-1981. - Tech. Rep. Inst. Meeresk. Hamburg 1-86, 1-201.

Hickel, W., Bauerfeind, E., Niermann, U. \& Westernhagen, H. von, 1989. Oxygen deficiency in the south-eastern North Sea: Sources and biological effects. - Ber. Biol. Anst. Helgoland 4, 1-143.

Irion, G. \& Müller, G., 1987. Heavy metals in surficial sediments of the North Sea. In: Heavy metals in the environment. Ed. by S. E. Lindberg \& T. C. Hutchinson. CEP Consultants Ltd., Edinburgh, $2,38-41$. 
Irion, G. \& Müller, G., 1990. Sedimentary processes in the North Sea as revealed from heavy metal distribution in sediment cores. - C.M./ICES E 16,1-8.

Karbe, L., Gonzalez-Valero, J., Borchardt, T., Dembinski, M., Duch, A., Hablizel, H. \& Zeitner, R., 1988. Heavy metals in fish and benthic organisms from the northwestern, central and southern North Sea: regional patterns comparing Dab, Blue Mussel and Hermit Crab. - C.M./ICES E 22, $1-17$.

Kersten, M. \& Klatt, V., 1988. The trace metal inventory and geochemistry of the North Sea shelf sediments. - Mitt. geol.-paläont. Inst. Hamburg (SCOPE/UNEP Sonderbd) 65, 289-311.

Kersten, M. \& Kröncke, I., 1992. Bioavailability of lead in North Sea sediments. - Helgoländer Meeresunters. 45, 403-409.

Kirkegaard, J. B., 1969. A quantitative investigation of the central North Sea polychaeta. - Spolia Zool. Mus. haun. 29, 1-285.

Kröncke, I., 1987. Lead and cadmium concentrations in selected macrofauna species from the Dogger Bank and the eastern North Sea. - Helgoländer Meeresunters. 41, 465-475.

Kröncke, I., 1988. Macrofauna standing stock of the Dogger Bank. A comparison: I. 1951-52 versus 1985. - Mitt. geol.-paläont. Inst. Hamburg (SCOPE/UNEP Sonderbd) 65, 439-454.

Kröncke, I., 1990. Macrofauna standing stock of the Dogger Bank. A comparison: II. 1951-52 versus 1985-87. Are changes in the community of the northeastern part of the Dogger Bank due to environmental changes? - Neth. J. Sea Res. 25, 189-198.

Kröncke, I., 1991. The macrofauna distribution on the Dogger Bank in April/May 1985-87 (with an annex of unpublished data from Birkett of April/May 1952-54). - Ber. Biol. Anst. Helgoland 8 , $1-137$.

Pearson, T. H. \& Barnett, P. R. O., 1987. Long-term changes in benthic populations in some west European coastal areas. - Estuaries 10, 220-226.

Pearson, T. H. \& Rosenberg, R., 1978. Macrobenthic succession in relation to organic enrichment and pollution of the marine environment. - Oceanogr. mar. Biol. 16, 229-311.

Pearson, T. H., Gray, J. S. \& Johannessen, P. J., 1983. Objective selection of sensitive species indicative of pollution-induced change in benthic communities. 2. Data analyses. - Mar. Ecol. Prog. Ser. 12, 237-255.

Pearson, T. H., Josefson, A. B. \& Rosenberg, R., 1985. Petersen's benthic stations revisited. I. Is the Kattegat becoming eutrophic? - J. exp. mar. Biol. Ecol. 92, 157-206.

Pearson, T. H., Duncan, G. \& Nuttall, J,, 1986. Long term changes in the benthic communities of Loch Linnhe and Loch Eil (Scotland). - Hydrobiologia 142, 113-119.

Petersen, G. Høpner, 1977. The density, biomass and origin of the bivalves of the central North Sea. - Meddr Danm. Fisk. -og Havunders. N.S. 7, 221-273.

Purdom, C. E. \& Garrod, D. J., 1990. Fisheries on the Dogger Bank. - C.M./ICES G 66, 1-5.

Rachor, E., 1982. Indikatororganismen für Umweltbelastungen im Meer. - Decheniana (Beih.) 26, 128-137.

Rachor, E., 1990. Changes in sublittoral zoobenthos in the German Bight with regard to eutrophication. - Neth. J. Sea Res. 25, 209-214.

Radach, G. \& Bohle-Carbonell, M., 1990. Strukturuntersuchungen der meteorologischen, hydrographischen Nährstoff- und Phytoplankton-Langzeitreihen in der Deutschen Bucht bei Helgoland. - Ber. Biol. Anst. Helgoland 7, 1-127.

Ray, S., 1984. Bioaccumulation of cadmium in marine organisms. - Experientia 40, 14-23.

Redant, F., 1987. A bibliography on the effects of bottom fishing gear and harvesting techniques on the benthic biota. ICES Working Document to the Benthos Ecology Working Group, 8 pp.

Reise, K., 1982. Long-term changes in the macrobenthic invertebrate fauna of the Wadden Sea: are polychaetes about to take over? - Neth. J. Sea Res. 16, 29-36.

Reise, K. \& Schubert, A., 1987. Macrobenthic turnover in the subtidal Wadden Sea: the Norderaue revisited after 60 years. - Helgoländer Meeresunters. 41, 69-82.

Richardson, K. \& Olsen, O. V., 1987. Winter nutrient concentrations and primary production in the eastern North Sea. - C.M./ICES C 23, 1-7.

Riesen, W. \& Reise, K., 1982. Macrobenthos of the subtidal Wadden Sea: revisited after 55 years. Helgoländer Meeresunters. 35, 409-423.

Rosenberg, R. \& Möller, P., 1979. Salinity stratified benthic macrofaunal communities and long-term monitoring along the west coast of Sweden. - J. exp. mar. Biol. Ecol. 37, 175-203. 
Rosenberg, R., Gray, J. S., Josefson, A. B. \& Pearson, T. H., 1987. Petersen's benthic stations revisited. II. Is the Oslofjord and the eastern Skagerrak enriched? - J. exp. mar. Biol. Ecol. 105, 219-251.

Salzwedel, H., Rachor, E. \& Gerdes, D., 1985. Benthic macrofauna communities in the German Bight. - Veröff. Inst. Meeresforsch. Bremerh. 20, 199-267.

Schubert. A. \& Reise, K., 1986. Predatory effects of Nephtys hombergii on other polychaetes in tidal flat sediments. - Mar. Ecol. Prog. Ser. 34, 117-124.

Taylor, A. H. \& Stephens, J. A., 1983. Seasonal and year-to-year changes in the temperatures of the English Channel and the Southern North Sea, 1961-1976: a budget. - Oceanologica Acta 6, 63-72.

Tomczak, G. \& Goedecke, E., 1962. Monatskarten der Temperatur der Nordsee, dargestellt für verschiedene Tiefenhorizonte. - Dt, hydrogr. Z. (Erg.-H. B) 7.

Ursin, E., 1954. Efficiency of marine bottom samplers of the van Veen and Petersen types. - Meddr Danm. Fisk.-og Havunders. N.S. 1(7), 1-8.

Ursin, E., 1960. A quantitative investigation of the echinoderm fauna of the central North Sea. Meddr Danm. Fisk.-og Havunders. N.S. 2(24), 1-204.

Warwick, R. M., 1986. A new method for detecting pollution effects on marine macrobenthic communities. - Mar. Biol. 92, 557-562.

Warwick, R. M., Pearson, T. H. \& Rushwahyuni, 1987. Detection of pollution effects on marine macrobenthos: further evaluation of the species abundance/biomass method. - Mar. Biol. 95, 193-200.

Westernhagen, H. von, Hickel, W., Bauerfeind, E., Niermann, U. \& Kröncke, I., 1986. Sources and effects of oxygen deficiencies in the south-eastern North Sea. - Ophelia 26, 457-473.

Whittaker, R. H. \& Fairbanks, C. W., 1958. A study of plankton copepod communities in the Columbia Basin, southeastern Washington. - Ecology 39, 46-65. 